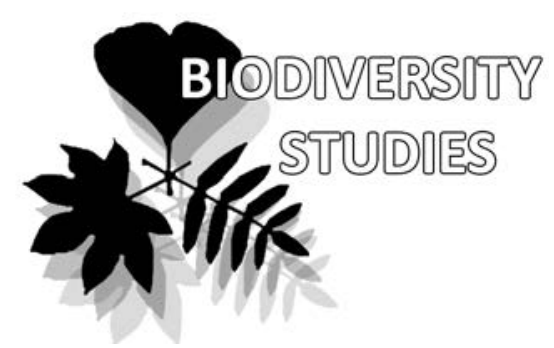

\title{
Bryophyte flora of the Magadan Province (Russia) I. Introduction and the checklist of mosses
}

\author{
Olga Yu. Pisarenko ${ }^{1 *} \&$ Vadim A. Bakalin ${ }^{2}$
}

Olga Yu. Pisarenko ${ }^{1 *}$

e-mail: o_pisarenko@mail.ru

Vadim A. Bakalin ${ }^{2}$

e-mail: vabakalin@gmail.com

${ }^{1}$ Central Siberian Botanical Garden

Novosibirsk 630090 Russia

${ }^{2}$ Botanical Garden-Institute FEB RAS

Vladivostok 690024 Russia

* corresponding author

Manuscript received: 27.06.2018

Review completed: 28.10 .2018

Accepted for publication: 02.11.2018

Published online: 06.11.2018

\begin{abstract}
A B S T R A C T
This paper presents the first of two parts of bryophyte flora study in the Magadan Province (Russia). It provides a review of the area's geography, climate, vegetation history and current vegetation cover. The checklist of the mosses recorded from the province summarizes all available data on the Magadan Province moss flora, including previously published reports, our own collections and other available specimens deposited in NSK, VBGI as well as MAG and LE. It also includes data on distribution of 364 moss species, 133 of which were not included in the prior summary of the mosses from the province by Blagodatskikh (1984). Each taxon is annotated with data on its frequency, distribution within the studied key plots, elevation and habitats. Despite the relatively large number of species recorded, the checklist is, nevertheless, preliminary. Bulk of taxa from the Magadan Province have been recorded from the western part of the province, whereas the eastern part still remains poorly investigated.
\end{abstract}

Keywords: bryophyta, Russian Far East, biodiversity, Kolyma, Okhotsk coast, Olskoye Basalt Plateau, phytogeography, North-East Asia

\section{P E 3 Ю M E}

Писаренко О.Ю., Бакалин В.А. Мохообразные Магаданской области (Россия) І. Введение и список мхов. Статья явАяется первой частью изможения результатов целенаправленного изучения флоры мохообразных Магаданской области; во вводной части дана характеристика физико-географических условий, климата и растительности. Основную часть составляет аннотированный список мхов МагаАанской области, составценный при обобщении результатов обработки собственных колмекций (NSK, VBGI) и опубмикованных ранее материалов, а также частичной ревизии образцов, хранящихся в MAG и LE. Список содержит Аанные о распространении 364 видов мхов, что на 133 виАа больше, чем приводилось в предыАущей обобщающей работе Благодатских (1984). А^я каждого вида указаны встречаемость, высотный диапазон, распределение по изученной территории и основные местообитания. Несмотря на значительное число зарегистрированных таксонов, список мхов Магаданской области явцяется предварительным, поскольку восточная часть территории остается очень слабо исследованной.

КАючевые слова: мхи, мохообразные, Российский Аальний Восток, биоразнообразие, фитогеография, Колыма, Охотское побережье, Ольское Базальтовое плато, Северо-Восточная Азия

\section{INTRODUCTION}

The Magadan Province remains one of the poorly studied regions of Russia in regards to its moss flora. Only within the last 40 years have bryologists taken an interest in the province, and even then, only a few taxa were reported before Dr. Lidia Savelievna Blagodatskikh's systematic attempt to document the bryophytes at the last quarter of the twentieth century. Over an approximately 15 year span, she conducted research on several local bryophyte floras, and summarized all of her collection data in the "Mosses of Kolyma Upland” (Blagodatskikh 1984). In addition to this valuable survey of the moss flora, Blagodatskikh (1988) also published the first account of the liverworts of the province.
The main problem facing the study of bryophytes in the Magadan Province is the poor network of roads within the province, which impedes fieldwork. The first road connecting the Magadan Province with the adjacent Republic of Yakutia was constructed in the last 30 years of the twentieth century. This road, in a broad sense, remains the only connecting corridor by land to other regions of Russia. Other roads are extremely local and very few. Due to the latter circumstance, the collecting localities visited by Blagodatskikh, as well by us, are located mainly along the federal route, Magadan-Susuman-Ust-Nera, and its branch through Khasyn-Omchak (Fig. 1). The summary published by Blagodatskikh (1984) lists 234 moss taxa and is a major contribution to the knowledge of the moss diversity both in 


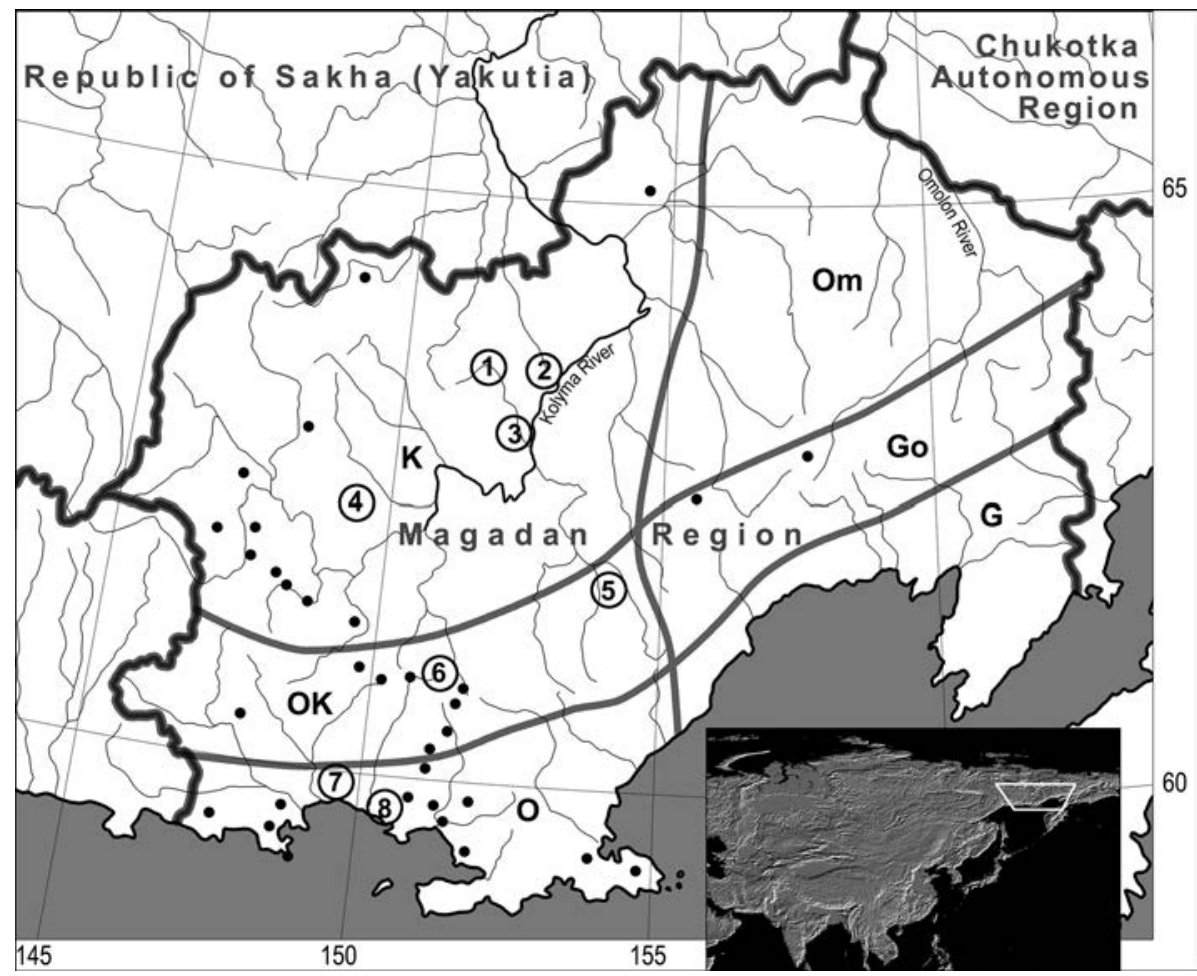

Figure 1 The exploration of the Magadan bryophyte flora. Black dots show localities cited by Blagodatskikh (1984), circled numbers from 1 to 8 are the localities investigated by our current research in 2010-2014 (see Table 3 for description). Borders of floristic districts are after Khokhriakov (1985) and Berkutenko et al. (2010). Abbreviations for the floristic districts are K - Kolymsky, OK - Okhotstko-Kolymsky, O - Okhotstky, GO - Gizhigsko-Omolonsky; G - Gizhigsky and $\mathbf{O m}$ - Omolonsky (for the last two districts there are no bryological data)

the province as well as in North-East Asia. The specimens collected by Blagodatskikh are mostly deposited in LE. This material has since been used in monographs of several genera for the Russian moss flora, including, among others, those by Czernyadjeva (1999, 2004), Ignatova \& Muñoz (2004), Afonina \& Blagodatskikh (2006), Afonina \& Ignatova (2007), Afonina (2008), Ignatov \& Ignatova (2008), Maximov \& Ignatova (2008), Fedosov \& Ignatova (2011), Ignatov (2012), Fedosov (2012) and Ivanova et al. 2014.

Only a few new bryophyte reports from the Magadan Province have been published since Blagodatskykh's (1984) work. Most of these were made during the course of our work, although a few were added by the collections of other researchers (Chemeris \& Mochalova 2015).

The present paper is the first of two parts devoted to the description of the bryophyte flora of the Magadan Province. The main goal of part one is to provide a general overview of the province, the collecting localities and to list the recorded mosses. Part two will detail the recorded liverworts in the province as well as summarize the bryophyte flora.

\section{STUDY AREA \\ Climate}

Meteorological stations are very scattered across the Magadan Province and are mostly located in settlements within river valleys. Consequently, the latter provide some limitations towards an understanding of real climate in the areas under investigations. Very approximate information for the province is summarized in Table 1.

The current climate is characterized by short and relatively cool summers, although these can be locally hot and dry in ultracontitental areas. The winters are long and cold with minimum temperatures reaching $-60^{\circ} \mathrm{C}$ and lower. Some regional variation occurs in the areas adjacent to the coastal line, with a relatively strong influence observed at the nearest 15-20 $\mathrm{km}$ from the sea shore (Yurtzev 1974, Berkutenko et al. 2010), however by large valleys wet air masses sometimes able to spread for 100 and even $200 \mathrm{~km}$ northward from the Sea of Okhotsk. Along the sea coast, the summer is foggy, wetter and much colder than in inner areas of the Kolyma Plateau. The opposite situation is characteristic of winters when coastal areas have much warmer weather than the interior of the Kolyma Upland. The average annual temperature in the Magadan region varies from - $2-$ $-3^{\circ} \mathrm{C}$ on the coast of the Sea of Okhotsk to $-11--13^{\circ} \mathrm{C}$ in the continental districts. The thermoregulatory role of the sea provides a relatively long frost-free period: as a rule, on most of the coast, the temperatures below zero in Celsius scale begin in the third month of September and end in the first month of June; the duration of the frost-free period exceeds an average of 100 days. In continental areas in some years, the frost-free period (the duration of days without even morning frost exceeds 30 days) is not observed. Winter in the Magadan region lasts from 6 months in the South to 7.5 months in the North. Snow occurs on average by the middle of October (in some years to a month earlier) and disappears by May. The Magadan Province is situated completely in the land with permafrost ground distribution. Sometimes this results in additional wetting of the ground and development of swampy communities (although the mountainous relief commonly impedes these processes) and making soils poor in nutrition and acidic for plants.

\section{Vegetation}

The vegetation of the Magadan Province possesses a Hemiarctic nature (Fig. 2) and is completely included in the Hemiarctic (=Hypoarctic) Botanical-Geographical zone, in the sense of Yurtzev (1966). However, the vegetation and flora at its southernmost extreme is noticeably different from the remaining land and possesses a somewhat transitional character to the Boreal (taiga) zone (Yurtzev 1966). Various types of mountain tundras are widely distributed in the Magadan Province. The communities similar to the arctic 
Table 1. The climate characteristics (by: Kovel' 1990). Plot studied are numbered according Fig. 1; Floristic district are named according to Khokhriakov 1985.

\begin{tabular}{|c|c|c|c|c|c|c|}
\hline $\begin{array}{l}\text { Floristic district } \\
\text { (number of plot) }\end{array}$ & $\begin{array}{l}\text { Nearest meteostation (with Cyrillic } \\
\text { script), coordinates, altitude }\end{array}$ & $\begin{array}{c}\text { Mean annual } \\
\text { temperature, } \\
\text { T, }{ }^{\circ} \mathrm{C}\end{array}$ & $\begin{array}{c}\text { Mean January } \\
\text { temperature, } \\
\text { T, }{ }^{\circ} \mathrm{C}\end{array}$ & $\begin{array}{c}\text { Mean July } \\
\text { temperature, } \\
\text { T, }{ }^{\circ} \mathrm{C}\end{array}$ & $\begin{array}{l}\text { Average frost- } \\
\text { free period, } \\
\text { days }\end{array}$ & $\begin{array}{l}\text { Average an- } \\
\text { nual precipi- } \\
\text { tation, mm }\end{array}$ \\
\hline Kolymsky (1) & $\begin{array}{l}\text { Canyon (Каньон) } \\
63^{\circ} \mathrm{N}, 152^{\circ} \mathrm{E} ; 686 \mathrm{~m} \text { alt. }\end{array}$ & -11 & -30.7 & 12.2 & 48 & 484 \\
\hline Kolymsky (4) & $\begin{array}{l}\text { Yagodnoye (Ягодное) } \\
63^{\circ} \mathrm{N}, 150 \mathrm{E} ; 504 \mathrm{~m} \text { alt. }\end{array}$ & -11 & -33.3 & 14.2 & 51 & 390 \\
\hline$-/ /-$ & $\begin{array}{l}\text { Jack London Lake (оз. Ажека Аондона) } \\
62^{\circ} \mathrm{N}, 149^{\circ} \mathrm{E} ; 808 \mathrm{~m} \text { alt. }\end{array}$ & -11.2 & -30.4 & 12.1 & 70 & 306 \\
\hline $\begin{array}{l}\text { Okhotstko- } \\
\text { Kolymsky (5) }\end{array}$ & $\begin{array}{l}\text { Omsukchan (Омсукчан }) \\
63^{\circ} \mathrm{N}, 156^{\circ} \mathrm{E} ; 526 \mathrm{~m} \text { alt. }\end{array}$ & -11.1 & -33.4 & 13.2 & 49 & 297 \\
\hline $\begin{array}{l}\text { Okhotstko- } \\
\text { Kolymsky (6) }\end{array}$ & $\begin{array}{l}\text { Madaun (Мадаун) } \\
61^{\circ} \mathrm{N}, 151^{\circ} \mathrm{E} ; 523 \mathrm{~m} \text { alt. }\end{array}$ & -9.5 & -29.8 & 13.0 & & 355 \\
\hline Okhotstky (8) & $\begin{array}{l}\text { Magadan (Магадан }) \\
60^{\circ} \mathrm{N}, 151^{\circ} \mathrm{E} ; 115 \mathrm{~m} \text { alt. }\end{array}$ & -3.5 & -17 & 11.2 & 114 & 526 \\
\hline
\end{tabular}

tundras are observed at the elevations exceeding 1000 and more meters a.s.l. The fundamental difference between the Hemiarctic tundras (southern and typical) from the arctic ones is in their origin. The former may be called a north taiga derivate and is somewhat similar to the vegetation ground cover developed under canopy of boreal forests (Yurtzev 1966). Other common types of vegetation are lightened larch forest and scattered larches, Pinus pumila thickets, swamps and meadows. Below we provide a short review of the basic communities with the main attention to those where bryophytes were collected.

The large river floodplains are occupied by Populus-Chosenia forests with a light or more robust admixture of various tall willows. Kharkevich (1984) and later Khokhryakov (1989) suggested that these forests were possibly strongly transformed derivates of the so-called 'arcto-tertiary' (= 'arctoboreal') forests. Not contesting this assertion, it is worth noting that the bryophyte flora could hardly confirm this statement, due to the absence of temperate (and poor presence of bryophytes at all) taxa that result from tall grass ground cover. The taxa growing along watercourses are virtually the same as those found in similar habitats in other community types. The only suitable habitat are tree trunks, and the latter mostly concerns the mosses, because hepatic epiphytes are absent in these northern localities. Many of the common epiphyte, and even epixylous mosses of the boreal forests, only occur in the floodplain forests of the Magadan region (Amblystegium serpens, Campylophyllopsis sommerfeltii, Dicranum fragilifolium, D. montanum, Pylaisia polyantha, P. selwyniz) or mainly (Brachythecium mildeanum, Climacium dendroides, Hygroamblystegium bumile, $H$. varium, Plagiomnium curvatulum, Pseudoleskeella nervosa, Rhizomnium magnifolium).

There are also taxa associated with ephemeral floodplains (like Riccia sp.), but those taxa have no genetic connection (in floral aspect) to the floodplain forests.

The crooked forest formed by Betula lanata were regarded by Khokhryakov (1989) as communities genetically related to the floodplain ones. Their distribution (as continuous communities with birch dominating, but not as isolate clumps) is limited by a narrow band along the northern coast of the Sea of Okhotsk. Althouhg Betula lanata occurs northward, it rarely forms continuous communities. Several shrubs, like Rosa spp., Sorbus sambucifolia, Pinus pumila are commonly occurring in birch forests as understory. The communities with Betula lanata house several species of the taiga zone, but none of them are specific to the birch forests in the Magadan Province.

The distribution patterns described for Betula lanata communities are very similar to those of Dusheckia fruticosa. The latter is also distributed mostly along seacoasts, although spreading northward more widely, where they form rims along watercourses or clumps in wet well-drained slopes. In general, Betula lanata and Duschekia fruticosa communities in the areas adjacent to the Sea of Okhotsk are tightly connected and somewhat 'intergrade' into one another. The majority of taxa occurring in Duschekia thickets are not specific to them, although coastal Alneta houses some rare taxa whose distribution is limited in the Magadan Province by this type of community. For instance, Rhytidiadelphus subpinnatus, R. triquetrus, Myuroclada longiramea, M. maximowiczii and Herzogiella adscendens were observed along the Sea of Okhotsk only, or were mainly growing along stream banks in crooked Betula forests and Duschekia fruticosa thickets. Almost the same can be said about Trachycystis flagellaris, Dicranum polysetum and Bartramiopsis lescurii. The only locality for Mylia verrucosa in the Magadan Province is in the Duschekia crooked forest along small streams near Magadan city. Furthermore, it is worth noting that the latter species sporadically occurrs along the western coast of the Sea of Okhotsk, but is not found in the Kamchatka Peninsula in much more southern latitudes. This may confirm the theory emphasized by Kharkevich (1984), and discussed by many other authors starting from Komarov (1950), who argued that this land was inhabitedmostly from the north, but not from the south (via Kurils), thus by taxa passing through the 'hypoarctic filter' as in Yurtzev's (1974) terminology.

The larch forests (Fig 2: D, G) formed by Larix cajanderii occupies large landscapes, although rarely form dense canopies and mostly presented by lighted swampy forests or larch trees scattered over shrubby vegetation or solitary crooked shrubby trees (sprawled form). The larch forests are, as usual, developed over well-drained mountain slopes, 


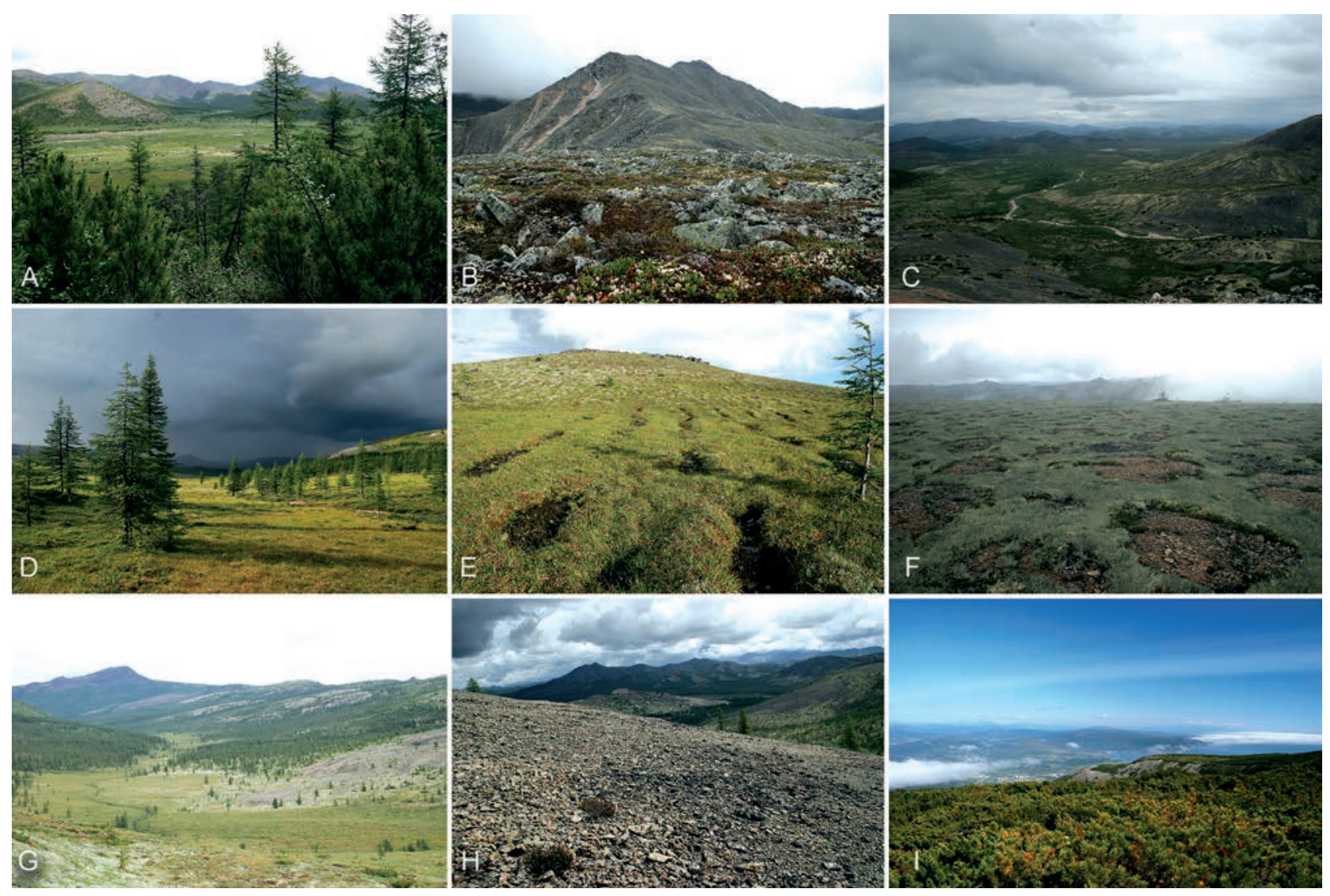

Figure 2 Landscape photographs: A - Bolshoi Annachag Range (Kolymsky floristic district), central part: Sukhokhy River valley in upper course, from a slope covered by scattered Larix, B - Bolshoi Annachag Range (Kolymsky floristic district), central part: spotty stony dwarfshrub tundra, covering well-drained watersheds and slopes near ridgeline; C - Bolshoi Annachag Range (Kolymsky floristic district), central part: Sukhokhy River upper course, 'goltzy' ( alpine heathlands) landscape; D - Olskoye Basalt Plateau (Okhotstko-Kolymsky floristic district), south of Skif Mt.: timberline is formed by crooked Larix cajanderii trees; E - Olskoye Basalt Plateau (Okhotstko-Kolymsky floristic district), south of Skif Mt.: swampy tundra on a slope with a specific micro-relief created by moving water and frost; F - Olskoye Basalt Plateau (Okhotstko-Kolymsky floristic district), south of Skif Mt.: flat summit of small ridge with lichen tundra and stony spots as the result of cryoturbation (the process of mixing of substrate due to repetitive processes of freezing/defreezing); G - Olskoye Basalt Plateau (OkhotstkoKolymsky floristic district), south of Skif Mt.: inversion in altitudinal distribution of plant communities: Larix forests on gentle slopes, lichen stony tundra on steep slopes, boggy sedge and Kobresia tundra in flat valley bottom; H - Olskoye Basalt Plateau (Okhotstko-Kolymsky floristic district), south of Skif Mt.: bare stone fields take huge area in high elevations of Kolyma Upland; I - Okhotsk coast vicinity Magadan city, Marchekanskaya hill (Okhotstky floristic district), Pinus pumila in lower altitudinal belt near sea shore. Photos by Pisarenko, 2014.

commonly with shrubs, including Pinus pumila in the understory, and ground cover composed by dwarf shrubs and meso- to xero-mesophitic mosses. The swampy lighted larch forests occur more rarely. The dominant ground cover is Sphagnum spp. and several ericoid dwarf shrubs. The larch forests are very light, decaying wood is commonly dry, and obligate epixylous taxa are rare or absent in this kind of forests. The bryophyte composition in the ground cover drastically varies from the absence of mosses (in forests with grass cover) to xero-mesophytes (like Rhytidium rugosum, Barbilophozia barbata, Lophoziopsis excisa) or, under more wet conditions, exhibit the type of vegetation typical of mires (Sphagnum spp., Aulacomnium palustre, A. turgidum). The epiphytes are rare in larch forests (only Ptilidium pulcherrimum was observed among the liverwort collections).

Pinus pumila thickets (Fig. 2: I) occupy large landscapes and the latter is the common edificator of communities. However the density of the canopy as well as the distribution frequency is much lower than in, e.g. the Kamchatka
Peninsula. The latter is the direct consequence of poor snow cover in the winter. It is worth noting that although dwarf pine communities are commonly regarded to be tantamount to taxonomically poor floras (due to the absence of the both typical alpine and forest taxa), the situation in the Magadan Province is somewhat different. Due to the lighted character of those communities, the quantity of boreal (forest) taxa exceeds the number of boreal taxa in larch forests. Moreover, some temperate taxa (the striking example is Bazzania trilobata) occur here.

The forestless landscapes (Fig 2: A-C, E, F, H) are quite diverse in the Magadan Province and may be subdivided into the following types.

Alpine communities at apical part of narrow ranges along the Sea of Okhotsk. The peculiar trait of this habitat is the absence of forests that could be explained by low temperatures, but is a consequence of rather dry (well-drained) substrates, severe wind regime and very thin snow cover during thewinters. The potential for altitudinal 
distribution of Pinus pumila (or, even, 'normal' trees) is not maximized there, as it is in the more southerly Kurils, Sakhalin and southern Sikhote-Alin.

Moist tundras, including communities somewhat intermediate between tundras and alpine meadows and swamps, developed due to a complexity of factors, including (each factor may play the role of various value): low temperatures, thermal inversions, and over-wetting. The floristic difference between moist mossy tundras and meso- or even oligotrophic mires are lessened. The high levels of moisture results in a sudden increase of taxonomic diversity of liverworts (with the exception of mesotrophic moss-grass meadows, where the number of bryophyte species is not so high).

Drier, flattened forestless landscapes in apical portions of smoothened hills and mountains at middle elevation and drier slopes above timberline in the interior part of the Kolyma Upland. The absence of forests in those areas is the result of low temperatures as well as dryness of substrates (due to high drainage abilities). The presence of mosses and liverworts there is largely dependent on local moisture. In areas with some amount of percolate water, small-sized communities similar to those near small streams may be observed. In other cases, the liverworts occupied relatively moist cliff crevices (a rare occasion in the Kolyma Upland) and fine soils in the crevices between stones in stony fields.

The communities forming the banks along streams contain a special complex of bryophytes (the banks of large streams and, especially rivers are commonly taxonomically poor due to regular disturbance of vegetation cover during floods or due to high coverage by grasses and shrubs). This type of habitat is the richest for both liverworts and mosses. Due to the 'azonality' of this habitat, it only slightly differs across altitudinal levels. Only a few taxa occurring in upper elevation levels do not occur down along the stream courses. Moreover, in some cases the absence of alpine taxa in the lower courses may be explained by changes in bedrock composition, but not in the climate change across an altitudinal gradient (it is worth mentioning that climatic changes are not as drastic as they are in more southerly latitudes, since the Magadan Province lies completely in the Hemiarctic, smoothing the difference between the stream bank floras of the lower and higher elevations). Closely connected to stream bank communities are those developed in snowbed habitats. The latter type of habitat is a relatively rare occasion in the inner part of the Kolyma Upland, due to high drainage abilities of the substrata (water from mel- ting snow going directly underground at the place of its melting instead of spreading and forming overwetted soils). However, where the situation is different, the peculiar nival complexes can be observed, being nevertheless poorer in taxa than the sources of small streams in tundras.

The distribution of vegetation communities is closely related to the chemical composition and structure of the ground (or bedrocks). For the most part, the Kolyma Upland is open to the sun by argillaceous slates - an exceedingly loose and well-drained substrate. Then, only xeric communities relatively poor in bryophytes (although containing some specific mosses, like Aloina rigida) are developed. $\mathrm{Cu}-$ riously, even limestone substrates are more 'waterproof' than argillaceous slates. This is one of the reasons for the comparatively high diversity (both in vascular plants and bryophytes) observed in the Olskoye Basalt Plateau (regarded as a floristic 'oasis' by Yurtzev \& Khokhryakov 1975), where basalts form firm waterproof beds and promote the development of a water-dependent flora. The granitic bedrocks are opened rarely in the Kolyma Upland. The largest outcrops are along the Sea of Okhotsk in units with a wetter climate and promote the formation of a flora with many meso- and hygrophytes.

It is worth noting that the vegetation cover in some inner areas of the Kolyma Plateau is in contrast between nominal precipitation amount and the meso-hygrophitic character of the flora in most of the localities. This may be explained by the durable foggy period when the precipitation amount is formally almost nil, but evapotranspiration also remains very low, resulting in the survival of a highly water-dependent flora.

The nominal structure of vegetation within three reviewed geobotanical districts is summarized in the Table 2 and briefly annotated below (Berkutenko et al. 2010).

Chersko-Verkhoyansky geobotanical district (= Kolymsky floristic district) is characterized by a lower altitudinal belt covered by lighted and swampy Larix forests, becoming crooked and with Pinus pumila understory near the upper limit. The large areas are covered by mountain tundras of various composition and gravelly barrens. Some dry slopes are occupied by scattered steppe vegetation.

Okhotsko-Magadansky geobotanical district is characterized by the dominance of lighted Larix forests. The timberline occupies 600-650 $\mathrm{m}$ a.s.l. (considerably lower than it is inland!), below timberland, dwarf pine (Pinus pumila) are common, and below $400 \mathrm{~m}$ a.s.l. change to larch and birch-larch forests.

Table 2. The structure of vegetation cover of geobotanic districts, where bryophytes were collected, coverage in persentage

\begin{tabular}{lccc}
\hline Vegetation type & Okhotsko-Magadansky & Kolymsky mountainous & $\begin{array}{c}\text { Chersko-Verkhoyansky } \\
\text { mountainous }\end{array}$ \\
\hline Hemiarctic tundras & 8.8 & 5.3 & 6.5 \\
Pinus pumila thickets & 23.9 & 22 & 16.8 \\
Scattered and lighted Larix-forests & 39.6 & 34.2 & 47.2 \\
Populus-Chosenia floodplain forests & 1.5 & 0.3 & 0.2 \\
Shrubby thickets & 4 & 4.1 & 4.1 \\
Mires & 10 & 1.4 & 2 \\
Meadows & 1.8 & 0.3 & 0.3 \\
Alpine gravelly barrens and tundras & 10.4 & 32.4 & 22.9 \\
\hline
\end{tabular}


Kolymsky mountainous geobotanical district (= Okhotsko-Kolymsky floristic district) is somewhat superficially similar to the Chersko-Verkhoyansky mountainous geobotanical district. The lower altitudinal levels are covered by relatively low (less $15 \mathrm{~m}$ tall) lighted larch forests, with dense dwarf pine understory in the upper elevations and in the dry river terraces. The alpine tundras and gravelly barrens are similarly widely distributed. The peculiar trait of this vegetation in the district are wider distributions of Pinus pumila, lower timberline and virtual absence of steppe communities, all listed are a consequence of wetter and colder summers.

\section{General trends in flora formation in the Upper Pleistocene and the Holocene}

Knowledge of the flora of the Magadan Province (largely corresponding to the Kolyma Upland), is valuable for the understanding of the origin of the flora (in a broader scale - for biota development) in North-East Asia. Magadan Province covers the South-Western part of the so-called Mega-Beringia and is, on one hand, a refugia for relicts of the cryo-xeric stage of biota development, while, on the other hand - provides a link between the migration routes uniting boreal (taiga) and alpine floras of East Siberia with the Beringian sector of the Hemiarctis (Yurtzev 1966). The Kolyma Upland is also a place of origin for numerous autochthonous elements, although the latter mostly applies to the vascular plants rather than to bryophytes which have exceedingly low speed of speciation.

As Yurtzev \& Khokhryakov (1975:129, translated from Russian original by VB and OP) wrote "the essential trait of Kolyma Upland geography is its position in the closest neighborhood of ultracontinental climate (North East Yakutia) and areas with oceanic climates (Sea of Okhotsk shore) that house highly contrasting floristic complexes". The consequence of this proximity, as referenced by these authors, is the somewhat instability of the coenotic position of the taxa belonging to both the contrasting groups, as well as the somewhat dualistic nature of the North-Okhotsk Province composition.

Presently there is much paleobotanic evidence that, in general traits, supports Yurtev's point of view (Yurtzev 1966, 1974, etc.). To simplify, the genesis of vegetation cover in the Magadan Province may be described by the following steps. The general cooling trend became obvious at least at the end of the Miocene and is accessed as the maximum in the Pleistocene glaciations. The evidence that would undisputably confirm the presence of early Quaternary glaciations (corresponding to Biber, Danube, Günzburg, Haslach and Mindel of Western Europe) are absent in the Magadan Province. Whereas, the synchronous cooling to European Riss in North East Asia has robust confirmations. Even better are the unambiguous data on the two stages of the last cooling, synchronous to European Würm I and II, and referred to here as Zyryanskoye and Sartanskoye glaciations, divided by the Karginskoye interstadial phase.

In this aspect, there is pronounced interest in obtaining data on the vegetation development due to paleobotanical reconstructions for the areas situated near or in the localities we studied for bryophyte diversity. In general, the intensive research at the edge of twentieth and twenty-first centuries (the review by Lozhkin 1997) showed that the Ka- zantzevskoye interglacial stage (before the Zyryanskoye glaciation) possessed more wet and warm summers (for $4-8^{\circ} \mathrm{C}$ higher) than at present. At the same time, the January temperatures in the land adjacent to the Arctic Ocean were for $12^{\circ} \mathrm{C}$ lower than that now, although in other areas, were similar or even higher than at present. Boreal forests in the Kazantzevskoye interglacial stage (preceding to the Zyryanskoye glaciation) is similar to the present cenoses distributed for $1000 \mathrm{~km}$ southward. Larix spread northward to the land occupied now by coastal tundra plains in Chukotka. The vegetation in the Kargiskoye interstadial time correspond to climates that were cooler than now, as seen by the receding northern forest line, and wide development of wormwood-shrub 'tundra' with clumps of Pinus pumila, Betula and Duschekia. The critical boundary of climatic change (and, as a consequence, florogenetic lines) occurred about 12000-12500 BP, when xeric grass communities (called tundras by Lozhkin, but probably represent tundrasteppes) were changed to shrubby birch tundras and then to Betula-Duschekia-shrubby communities. The climatic fluctuations within the last 2000 years have not resulted in considerable changes in vegetation cover. For example, the European 'little glaciation age' was not confirmed here. A significant find within the end of twentieth century was the similarity of the pollen spectra in the current arctic tundras in Wrangell Island with those of the last (Sartanskoye) glaciation, confirming the similarity of the vegetation structure between then and now.

The analysis of sediments in Vodopadnoye Lake (near Magadan city, locality 8) covers the time from the Atlantic stage of the Holocene, and initially shows a larger than now distribution of grass and grass-wormwood communities. Anderson et al. (2000) explain the latter by indicating that a slight cooling occurred in the climate at that time. After the Atlantic period, the vegetation exhibits uneven, but a steady increasein Pinus pumila, Betula lanata, Larix and 'Alnus' (probably Duschekia).

Available data on the Sea of Okhotsk - Kolyma River mega-watershed (Chyornoye and Priyatnoye Lakes surroundings, ca. $61^{\circ} 01^{\prime} \mathrm{N} 151^{\circ} 43^{\prime} \mathrm{E}, 850-900 \mathrm{~m}$ a.s.l., near locality 3) covers the time from the Zuryanskoye glaciation to the present (Lozhkin et al. 2000). During the Zuryanskoye glaciation, there was a dominance of Selaginella rupestris (the most common taxon of cryo-xeric epochs in the Kolyma Upland) with the dominant vegetation described as 'tundragrass' and 'grass-shrub' communities. The palynological spectra for $11000 \mathrm{~PB}$ characterize this vegetation as AlnusBetula krumholtz. In the Preboreal stage of the Holocene the strong increase of Pinus pumila notes a return to the previous Boreal distribution and the beginning of the Atlantic stages. Within the Atlantic stage, the timberline began going down and the altitudinal 'width' of the Pinus pumila belt became wider, the presence of Duschekia decreased, but this was compensated by the increased coverage of communities with Artemisia (cited authors describe this as wormwood communities dominance in well-exposed slopes). During the Subboreal and the Subatlantic stages, the vegetation (Lozhkin et al. 2000) may be characterized as combinations of Pinus pumila-Duschekia-Betula-Larix 
with a large percentage of ericoid dwarf shrubs and peat mosses. The latter may confirm the development of moist communities with Ericaceae (like moist hummocky tundras). The vegetation at that time exhibits features closeest to the current. The data on the adjacent areas (Annachag Range: Lozhkin 1997) confirm vanishing dwarf pines at the beginning of the Sartanskoye glaciation and further development of 'wormwood-grass' tundra. Later, as far as $12500 \mathrm{BP}$, the grass tundra over the period less than 1000 years was replaced by Betula-Duschekia krumholtz and then lighted Larix forests. The next expansion of Pinus pumila took place about $9000 \mathrm{BP}$, when associations similar to the present were formed.

The reconstruction of vegetation changes at Smorodinovoye lake (about $100 \mathrm{~km}$ northward from locality 3) showed that the vegetation at $22000 \mathrm{BP}$ was a mosaic of various vegetation communities such as xerophilous grasses and Selaginella in steep slopes, and wetter sedge-moss and sedge-grass communities with creeping willows. These are not the so-called uniform 'mammoth tundra-steppe' as it would be expected (Anderson et al. 1998: 36). The grass tundras were quickly changed for shrubby-birch tundra about 12000 BP.

There are data on the vegetation development in the Armanskaya depression (near locality 7) from the end of the Pleistocene that cover stages from the Zyryanskoye glaciation to the present (Anderson et al. 1997). This area is of special interest because it is adjacent to the Sea of Okhotsk, and presumably should provide more moist environments due to the proximity of the sea. As it was shown (1.c.) the glaciation in the course of the Zyryanskoye glaciation was much more intense than in the inner areas of the Kolyma Upland. However, even there, within depressions, the glaciation was very thick (up to $600 \mathrm{~m}$ ice shield thickness), while in some upraised stations the ice cover was absent or very thin. In general, this glaciation had 'net' character. The areas occupied by ice during the Sartanskoye glaciation were smaller than in the Zyryanskoye one. Glaciers were up to $15 \mathrm{~km}$ in length in the valleys, but did not completely cover them. It is likely that possibile remnants of flora survived there from the time precedeeding the two last glaciations. It is interesting that despite the similarity of the vegetation in the course of glaciations in maximum cooling periods (Poaceae dominance, wide distribution of Selaginella), their are nevertheless elements of mesic vegetation, including wide distribution of Sphagnum, Cyperaceae, Sanguisorba, Cardamine, etc. This is probably the result of the relative proximity of the sea coast, that although was distanced from the Armansky (Kamennyy) Range for one or two hundredth kilometers southward due to shelf drainage in the course of glacio-eustatic process. The considerable changes of vegetation were noted (as in other sites of Kolyma Upland) for ca. 12300 BP. At that time, the large-scale reorganization of vegetation was common; it resulted in the replacement of the grass tundra by dwarf shrubdwarf birch tundra (30\% of birch pollen grains belong to shrubby birches, like Betula exilis). The Boreal period is characterized there by the largest distribution of forests (at the same time the forests reached the coast of East Siberian
Sea. Lozhkin \& Glushkova (1997) provided data on the vegetation changes in the lower course of the Ola River. They showed the larger than at present, distribution of forest vegetation not only in Boreal, but also in the Atlantic stages. Moreover, authors (1.c.) also evidently showed the formation of shrubby vegetation along watercourses 20000 BP (near maximum of glaciation!). The mentioned shrubby vegetation was composed by ericoid shrubs, willows and even solitary Pinus pumila (if the latter is not the result of longdistance pollen dispersal), whereas in most of the area, the meso-xirophilous communities were dominated.

There is some data on the most floristically interesting area in Kolyma Upland - the Olskoye Basalt Plateau (locality 6) and adjacent areas. The peat strata in the upper course of the Maltan River cover the interval from the end of the Sartanskoye glaciation (ca. 12000 BP) to the present (Lozhkin \& Glushkova 1997b). The general traits of vegetation changes correspond to the changes in other areas of the Kolyma Upland: grass dominance and absence (or very poor presence) of woody vegetation is changed to a dominance of forest and shrubby landscapes. The presence of spore-bearing plants remained more or less stable, although several sudden increases and then decreases were observed. These fluctuations probably were the result of local fluctuations and likely weren't connected with the general regularities of florogenesis.

It worth mentioning that some of the theoretical hypotheses by Yurtzev (1974) are partly confirmed (or at are least highly likely) as shown in the subsequent paleobotanic studies cited above:

1. The character of vegetation cover was different in various parts of Megaberingia during maximal cooling. In the middle part of Megaberingia (the usage of the tern is after Yurtzev 1974) the maximal cooling was characterized by dry a continental climate with relatively warm summers, whereas the climate in the northern extremes was strongly colder that in the interior and, in southern extremes the climate was wetter than the interior. The latter circumstance permitted the survival of many mesophytic elements including some woody taxa.

2. The basic traits of climates during the 'entrance' to the glaciation time were different from the climate traits at the 'exit' from glaciation. The 'entrance' time was characterized by cool and wet climate, whereas the exit - by warmer and drier climate.

The changes of water level in oceans were accompanied (in local aspect even promoted!) by climate changes when ocean coast 'receded.' Far northward, as far as Wrangel Island, was united with the continent, while almost the whole continental shelf was drained. Similar water level changes occurred southward the in the Sea of Okhotsk. most of these water level changes had the glacio-eustatic nature (e.g. Zyryanskoye and Sartanskoye glaciations), however sometimes they might be associated with the increasing of capacity of oceanic depressions. The valuable consequence of this water level changes and corresponding changes in coastal line position is the fact that the search for geographic relicts (meaning the taxa alien to the current vegetation that survived cooler conditions nearly in the same site where it 
occurs nowadays) is reliable in the middle part of Megaberingia, whereas: a) in northern extremities it may be under some doubts (with the exception of Wrangell Island) and b) inapplicable to mesophytic boreal elements of northern coast of the Sea of Okhotsk, that provides some warming and wetting influence not more than $20-30 \mathrm{~km}$ as in the present. The latter consequence, however, is likely to be doubtfull since, as Anderson et al. (1997) showed, the 'oceanic' influence at that time probably stretched as far as the Kamennyy Range, although, certainly, to a much lesser degree than it does now.

\section{MATHERIAL AND METHODS}

Between 2010 and 2014, V.A. Bakalin organized several expeditions to explore the bryoflora of the Magadan Province. A number of key areas in isolated localities could only be reached and surveyed by long distance hikes: Bolshoj Tuonnakh Range, Seimchan River upper course, Zamkovaya Mt., Olskoye Basalt Plateau, Kamennyj (=Armansky) Range in Okhotsk coast and others. Bakalin's own investigations were concentrated on hepatics, where he (by himself) collected a rather limited number of specimens, although larger collections were gathered under his supervision by E.N. Malashkina (2011) and A.V. Ermolenko (2012, 2013). The late V.Ya. Cherdantseva (1939-2013) initially identified the collections, revealing several new moss distribution records for the region (Cherdantseva \& Bakalin 2011, Malashkina 2012). Later, O.Yu. Pisarenko undertook fieldwork in the Magadan Province areas of Bolshoj Annachag Ridge and Olskoye Basalt Plateau, during the summer of 2014 (Pisarenko 2015a, 2015b, 2015c). She continued processing and determining the remaining aforementioned specimens.

The current paper summarizes the results of these specimens (ca. 2000 collections). A list of collection localities is provided in Table 3, and corresponds to the map in Fig. 1. It is easy to see that the vast majority of the province remains completely unexplored.

The localities are situated within three floristic districts of the Magadan Province (Fig. 1): Kolymsky, OkhotstkoKolymsky and Okhotstky (Khokhriakov 1985). The latter regionalization follows the recent Flora of vascular plants of Magadan Province (Berkutenko et al. 2010), although with name changes for (correspondingly): Cerska-Verkhoyansk mountainous, Kolyma mountainous and Okhotsk-Magadan geobotanic regions.

Most of the Kolyma Uplands is exposed to the sun by loose strata of argillaceous slates - a material with high drainage ability and commonly very dry and unfavorable for bryophytes. We were quite limited, therefore in finding suitable areas for study. Aside from this basic restriction, the main objectives for selecting collecting localities were 1) to find sites with more or less stable bedrock composition, 2) to cover areas along the sea shore as well as areas at a distance from it (inner part of the Upland) with drastically different climatic conditions, 3) to cover floras that develop on chemically various types of ground (limestone and basalts to granites) and 4) to cover all (or nearly so) the types of vegetation communities present in the Magadan Province. Table 1 provides a list of the main studied localities that can be divided into the following groups according to the aforementioned requirements:

locality 1 - dominant argillaceous slates with many bedrock outcrops composed by limestone and granites in ultracontinental climate;

locality 2 - dominant argillaceous slates with limestone outcrops in continental climate;

locality 3 - Kolyma upper course lowlands with some limestone outcrops and dominant argillaceous slates in continental climate;

locality 4 - dominant granite outcrops in ultracontinental climate;

locality $\mathbf{5}$ - dominant argillaceous slates with some metamorphic limestone dikes in continental climate;

locality $\mathbf{6}$ - 'alkaline' bedrocks composed by basalt, with some dikes(?) of granites in continental climate;

localities 7, 8 - granitic bedrocks in merely mild subcontinental climate along the shore of the Sea of Okhotsk.

The background studies conducted by vascular plants specialists (e.g. excellent Olskoye Basalt Plateau flora analysis by Yurtzev \& Khokhryakov 1975) made selecting localities easier in many cases.

Each specimen collected was annotated with the elevation, geographic coordinates, habitat (including presumable ground characteristics, shadiness, water availability, etc.) and associated taxa. Short plant community descriptions were compiled for the majority of occurring types with the practical purpose of sorting observed taxa within vegetation subunits.

\section{LIST OF SPECIES}

This list summarizes the authors' collections (VBGI, NSK) as well as the literature data, and specimens kept in MAG and LE with the latter only partly revised. Nomenclature follows Ignatov et al. (2006) with a few recent updates.

Each species is annotated by the template: its frequency - floristic districts where the species is known and author's locality numbers in case if they are (following Fig. 1 and Table 3) - altitude range (altitude belt) - main habitats. When the abbreviation of the floristic district is given without extension by localities or references, it means that the species is known for the district only from Blagodatskikh 1984.

The frequency is given as a rough estimate: commonsporadic-rare-unique (com-sp-r-un). Abbreviations for the floristic districts is $\mathbf{K}$ - Kolymsky, OK - Okhotstko-Kolymsky, O - Okhotstky and GO - Gizhigsko-Omolonsky. Abbreviations for the altitude belts are: $\mathrm{fb}$ - forest belt, $\mathrm{sb}$ - shrubs belt and $\mathrm{gb}$ - goltzi (=alpine, =forestless) belt.

The presence of sporophytes within a sample is marked "S+". For species which were collected 1-2 times only, full labels are cited. For samples which were collected/identified not by Pisarenko, the names of the the collectors are indicated. The citations of herbarium labels are given in square brackets, and the acronym of the herbarium in curly brackets.

Publications appearing after the account by Blagodatskikh (1984) was published are cited by floristic districts, with the exception for Pisarenko's works (2015a,b,c). Species added to the flora of the Magadan Province since the paper by Blagodatskikh (1984) are marked by an asterisk (*). The same concerns the regions for those the new records. 
Table 3. Collecting localities in Magadan Region.

\begin{tabular}{|c|c|c|c|c|c|}
\hline No & Locality & Altitude, $\mathrm{m}$ & Latitude, $\mathbf{N}$ & Longitude, E & Year - Collector \\
\hline 1 & $\begin{array}{l}\text { Kolyma Upland, Bolshoj Tuonnakh Ridge } \\
\text { Verina River basin }\end{array}$ & $\begin{array}{c}1100-2000 \\
650-800\end{array}$ & $\begin{array}{l}63^{\circ} 16^{\prime}-63^{\circ} 18^{\prime} \\
63^{\circ} 15^{\prime}-63^{\circ} 20^{\prime}\end{array}$ & $\begin{array}{l}151^{\circ} 02^{\prime}-151^{\circ} 06^{\prime} \\
151^{\circ} 25^{\prime}-151^{\circ} 32^{\prime}\end{array}$ & 2011 \\
\hline 2 & $\begin{array}{l}\text { Kolyma Upland in upper course of Kolyma River, } \\
\text { (Magadan State Nature Reserve), Zamkovaya Mt. area }\end{array}$ & $170-530$ & $63^{\circ} 20^{\prime}$ & $152^{\circ} 35^{\prime}$ & 2011 - Bakalin \& Malashkina \\
\hline 3 & $\begin{array}{l}\text { Basin of Seimchan River ca. } 60 \mathrm{~km} \text { upstream of } \\
\text { Seimchan Settl }\end{array}$ & $350-700$ & $63^{\circ} 17^{\prime}$ & $152^{\circ} 10^{\prime}$ & 2010 - Bakalin \\
\hline 4 & $\begin{array}{l}\text { Southern spurs of the Cherskii Mountain System, } \\
\text { Bolshoj Annachag Range }\end{array}$ & $800-1600$ & $62^{\circ} 07$ & $149^{\circ} 18$ & $\begin{array}{l}2014 \text { - Pisarenko } \\
\text { (Pisarenko 2015a) }\end{array}$ \\
\hline 5 & $\begin{array}{l}\text { Omsukchan District, Dyugadyak and Kilgana Rivers } \\
\text { watershed }\end{array}$ & $900-1400$ & $61^{\circ} 11^{\prime}-61^{\circ} 13^{\prime}$ & $153^{\circ} 54^{\prime}-153^{\circ} 59^{\prime}$ & 2012 - Bakalin \& Ermolenko \\
\hline 6 & Olskoye Basalt Plateau & $850-1460$ & $60^{\circ} 34^{\prime}-60^{\circ} 42^{\prime}$ & $151^{\circ} 14^{\prime}-151^{\circ} 32^{\prime}$ & $\begin{array}{l}2011 \text { - Bakalin \& Malashkina } \\
2014 \text { - Pisarenko }\end{array}$ \\
\hline 7 & Coast of the Sea of Okhotsk, Kamennyj Ridge & $400-1060$ & $59^{\circ} 47^{\prime}-59^{\circ} 49^{\prime}$ & $149^{\circ} 38^{\prime}-149^{\circ} 42^{\prime}$ & 2013 - Bakalin \& Ermolenko \\
\hline 8 & $\begin{array}{l}\text { Coast of the Sea of Okhotsk, Oksa River basin } \\
\text { Magadan surroundings }\end{array}$ & $\begin{array}{l}0-100 \\
0-700\end{array}$ & $\begin{array}{l}59^{\circ} 39^{\prime} \\
59^{\circ} 35^{\prime}\end{array}$ & $\begin{array}{l}150^{\circ} 29^{\prime} \\
150^{\circ} 56^{\prime}\end{array}$ & $\begin{array}{l}2011 \text { - Bakalin \& Malashkina } \\
\text { 2010-2014 - all }\end{array}$ \\
\hline
\end{tabular}

Authors' specimens are deposited in NSK and VBGI; full labels are incorporated into the Data Base Arctoa (http:// arctoa.ru/Flora/basa.php).

Abietinella abietina (Hedw.) M. Fleisch. - com - K: 1-4; OK: 5, 6; O; GO - 300-1300 m (fb, sb, gb) - rock outcrops and rock fields, dry tundra.

*Aloina rigida (Hedw.) Limpr. [BLAG] - un - K [Tenkinskii Distr., Nelkoba vicinity $\left(\sim 61^{\circ} 28^{\prime} \mathrm{N} 148^{\circ} 53^{\prime} \mathrm{E}\right), \sim 700 \mathrm{~m}$ alt., steep grassy slope to Ten'ka River 31.VII.1972 Blagodatskikh] $\{\mathrm{LE}\}$. The sample was reported as A. brevirostris (Blagodatskikh 1984).

Amblystegium serpens (Hedw.) Schimp. $-\mathrm{r}-\mathrm{K}: 2$, 4; O: 8 - 0-500 $\mathrm{m}$ (fb) - floodplains, rock outcrops, open grassy slopes $-\mathrm{S}+$.

*Amphidium lapponicum (Hedw.) Schimp. - r-OK: 5, 6; O: 7 - 900-1400 m (sb, gb) - rock outcrops - S+.

Amphidium mougeotii (Bruch et Schimp.) Schimp. un - OK [Olskoye Basalt Plateau; Yama and Ola Rivers upstreams $\left(\sim 60^{\circ} \mathrm{N} 151^{\circ} \mathrm{E}\right), \sim 1000 \mathrm{~m}$ alt., on boulders 5.IX.1972 Blagodatskikh] \{LE\}.

*Andreaea blyttii Schimp. - un - K: 4 [B. Annachag Ridge, upper part of E-macro slope, (62 $\left.10^{\prime} 26^{\prime \prime} \mathrm{N} 149^{\circ} 18^{\prime} 50^{\prime \prime} \mathrm{E}\right)$, $1470 \mathrm{~m}$ alt., on granite boulders on periphery of summer-persisting snow patch, 29.VII.2014] \{NSK\} - S+; O: 7 [Kamennyy Khrebet Range, upper course of Levaya Lankovaya River $\left(59^{\circ} 48^{\prime} 24^{\prime \prime} \mathrm{N} 149^{\circ} 40^{\prime} 30^{\prime \prime} \mathrm{E}\right), 690 \mathrm{~m}$ on boulder near small lake in mountain circus 7.VIII.2013 coll. Ermolenko] $\{$ VBGI $\}-$ S+.

*Andreaea nivalis Hook. - un - $\mathbf{O}$ (some collections in in different years from the same points) [Magadan city vicinity, Marchekanskaya hill $\left(59^{\circ} 30^{\prime} \mathrm{N} 150^{\circ} 48^{\prime} \mathrm{E}\right), 400 \mathrm{~m}$, on stones near snowbed. 13.IX.1977 coll. Afonina; 19.VII.1978 coll. Blagodatskikh \{MAG\}; 13.VIII.2014 coll. Pisarenko] \{NSK\}.

*Andreaea obovata Thed. - r - K: 1, 4-1200-1600 m (gb) - boulders - S+.

Andreaea rupestris Hedw. - sp - K: 1, 2, 4; *OK: 6 350-1600 m (fb, sb, gb) - boulders - S+.

Aplodon wormskioldii (Hornem.) R. Br. - un - K (vicinity Kulu Settlement, floodplain, Blagodatskikh 1984); O (vicinity Snezhnaya Dolina Settlement, floodplain, Blagodatskikh 1984) - floodplain.

Arctoa fulvella (Dicks.) Bruch et Schimp. - sp - K: 1, 4; *OK: 5; O - 1000-1600 m (gb) - nival habitats - S+.

Aulacomnium acuminatum (Lindb. \& Arnell) Kindb. $\mathrm{r}$ - K: 2; OK: 6; GO - 350-1100 m (fb, sb, gb) - open Larix forests, tundra, rock outcrops.
Aulacomnium palustre (Hedw.) Schwägr. - com - K: 1-4; OK: 5, 6; O: 7, 8; GO - 0-1400 m (fb, sb, gb) - wetlands, wet Larix forests, Betula exilis shrubs and tundra, wet niche among rock fields $-\mathrm{S}+$.

Aulacomnium turgidum (Wahlenb.) Schwägr. - com K: 1-4; OK: 5, 6; O: 7, 8; GO - 300-1400 m (fb, sb, gb) - Duschekia fruticosa thickets, open Larix forest, tundra, bogs and wet rock outcrops $-\mathrm{S}+$.

Bartramia ithyphylla Brid. - com - K: 1, 2, 4; *OK: 5, 6; O: 8 - 200-1600 m (fb, sb, gb) - crevices in rock outcrops, open grassy slopes, tundra, nival habitats $-\mathrm{S}+$.

Bartramia pomiformis Hedw. - r - K: 1; *OK: 5, 6; O 300-1400 m (fb, sb, gb) - crevices on rock outcrops, fine soil between stones $-\mathrm{S}+$.

* Bartramia subulata Bruch et Schimp. - un - K: 1 [B. Tuonnakh Mt. Range, Verina River upstream (631' $21^{\prime \prime N}$ $\left.151^{\circ} 03^{\prime} 04^{\prime \prime E}\right), 1200 \mathrm{~m}$ alt., on fine soil in niche among rockfield 25.VIII.2011 coll. Malashkina] \{VBGI, NSK\} - S+.

Bartramiopsis lescurii (James) Kindb. - un - O (Luzhin Bay, Betula forest and Duschekia fruticosa thickets, Blagodatskikh 1984) $\{\mathrm{LE}\}$.

Blindia acuta (Hedw.) Bruch et Schimp. - un - K (Vicinity Sibit-Tyehllakh Settlement, $\sim 600 \mathrm{~m}$, Blagodatskikh 1984); *O (Tanon-Serdyakh tundra, $100 \mathrm{~m}$, Chemeris \& Mochalova 2015).

Brachytheciastrum trachypodium (Brid.) Ignatov \& Huttunen - sp - K; OK: 6; O: 8 - 300-1450 m (fb, sb, gb) - open grassy slopes, stream banks, tundra.

*Brachythecium boreale Ignatov - r - K: 4; OK: 6 - 400 $1300 \mathrm{~m}$ (fb, sb, gb) - crevices on rock outcrops, stream banks, soil in dry gravelly tundra.

Brachythecium cirrosum (Schwägr.) Schimp. $-\mathrm{r}-* \mathrm{~K}$ : 2; *OK: 6; O - 20-1450 m (fb, sb, gb) - fine soil on rock outcrops.

*Brachythecium jacuticum Ignatov - r - O (Ignatov \& Milyutina 2010) - $300 \mathrm{~m}(\mathrm{fb})$ - crooked Betula forests and floodplains.

Brachythecium mildeanum (Schimp.) Schimp. $-\mathrm{r}-* \mathrm{~K}$ : 2; *OK: 6; O: 8 - 340-1460 m (fb, sb, gb) - floodplains, stream banks.

Brachythecium rivulare Schimp. $-\mathrm{r}-{ }^{*} \mathrm{OK}: 6$; O: 8 300-1200 m (fb, sb, gb) - stream banks.

Brachythecium turgidum (Hartm.) Kindb. - r - OK: 6 900-1200 m (gb) - wet Kobresia tundra, stream banks.

*Brachythecium udum I. Hagen - r - K: 4; O: 8 - 360 $1150 \mathrm{~m}$ (fb, sb) - Pinus pumila thickets, rock outcrops. 
Breidleria pratensis (W.D.J. Koch ex Spruce) Loeske un - OK: 6 [Olskoye Basalt Plateau, watershed of rivers Ola and B. Haya, (60³8'43"N 151 29'13"E), $1090 \mathrm{~m}$ alt., saddle between tops, wet tundra with Carex, Eriophorum, Kobresia spp., in moss cover, 5.VIII.2014] \{NSK\}.

Bryoerythrophyllum recurvirostrum (Hedw.) P.C. Chen - r-K: 1; *OK: 6; O: 8 - 0-1300 m (fb, sb, gb) - rock outcrops, tundra, stream banks $-\mathrm{S}+$.

*Bryoxiphium norvegicum (Brid.) Mitt. - un - O: some collections in in different years from the same cliffs along a stream near Magadan city, $300 \mathrm{~m}$ (Cherdantseva \& Bakalin 2011, Pisarenko et al. 2015) - S+

*Bryum algovicum Sendtn. ex Müll. Hal. - un - K: 1 [B Tuonnakh Mt. Range, Sources of Verina River $\left(63^{\circ} 17^{\prime} 31.4^{\prime \prime} \mathrm{N}\right.$ $151^{\circ} 25^{\prime} 29.3^{\prime \prime E)}, 1300 \mathrm{~m}$ alt., stream bank. 23.VIII.2011 coll. Malashkina, det. Zolotov] \{VBGI\} - S+. OK: 6 [Olskove Basalt Plateau, upper course of Ola River $\left(60^{\circ} 39^{\prime} 12.7^{\prime \prime} \mathrm{N}\right.$ 151¹6'30.0"E), $990 \mathrm{~m}$ alt., Pinus pumila-Alnus thicket, stream bank 7.VIII.2011 coll. Malashkina, det. Zolotov] \{VBGI\} - S+

*Bryum amblyodon Müll. Hal. - $\mathrm{r}$ - several specimens from the same locality collected in different years; some samples were treated by Zolotov. OK: 6 - 900-1100 m (gb) - tundra, rock outcrops.

*Bryum archangelicum Bruch et Schimp. - un - OK: 6 Olskoye Basalt Plateau, upper course of Ola River $\left(60^{\circ} 41^{\prime} 09.3^{\prime \prime} \mathrm{N} 151^{\circ} 14^{\prime} 44.1^{\prime \prime} \mathrm{E}\right), 1082 \mathrm{~m}$ alt. moss tundra. 12.VIII.2011 coll. Malashkina, det. Zolotov] $\{$ VBGI $-\mathrm{S}+$.

Bryum argenteum Hedw. - sp - K: 4; O - 0-600 m (fb) floodplains, eroded soil.

*Bryum bimum (Schreb.) Turner - R - K: 1; OK: 6 500-1100 m (fb, sb, gb) - wetlands, stream banks.

Bryum caespiticium Hedw. - un - O (Dukcha River) floodplain, on soil (Blagodatskikh 1984).

Bryum cryophilum Mårtensson - sp - K: 4; *OK: 6 1000-1200 m (gb) - stream banks.

*Bryum cyclophyllum (Schwägr.) Bruch et Schimp. - r - K: 2; OK: 6 - 900-1100 m (sb, gb) - stream banks.

*Bryum intermedium (Brid.) Blandow - un - OK: 6 Olskoye Basalt Plateau, upper course of Ola River

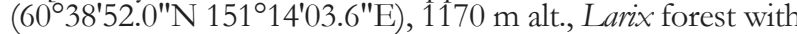
Sphagnum cover 11.VIII.2011 coll. Malashkina, det. Zolotov] $\{\mathrm{VBGI}\}-\mathrm{S}+$.

*Bryum knowltonii Barnes - un - OK: 6 [Olskoye Basalt Plateau; upper course of Maltan River $\left(60^{\circ} 39^{\prime} 33.3^{\prime \prime} \mathrm{N}\right.$ $\left.151^{\circ} 21^{\prime 2} 27.4^{\prime \prime} \mathrm{E}\right) 1190 \mathrm{~m}$ alt., 8.VIII.2011 coll. Malashkina, det. Zolotov] $\{$ VBGI $\}-\mathrm{S}+$.

*Bryum longisetum Blandow ex Schwägr. - un - OK: 6 - Olskoye Basalt Plateau, upper course of Ola River $\left(60^{\circ} 41^{\prime} 09.3^{\prime \prime} \mathrm{N} 151^{\circ} 14^{\prime} 44.1^{\prime \prime E}\right), 1082 \mathrm{~m}$ alt. moss tundra. 12.VIII.2011 coll. Malashkina, det. Zolotov] $\{$ VBGI $\}-\mathrm{S}+$.

*Bryum pseudotriquetrum (Hedw.) P. Gaertn. B. Mey. \& Scherb. - com - K: 1, 4; OK: 6; O: 8-300-1300 m (fb, $\mathrm{sb}, \mathrm{gb})$ - wetlands, stream banks.

Bryum weigelii Spreng. $-\mathrm{r}-$ *K: 4; O: 8-300-800 m (fb, sb) - streams and springs.

* Bucklandiella microcarpa (Hedw.) Bednarek-Ochyra \& Ochyra $-\mathrm{r}-\mathrm{K}: \mathbf{4}$; O: $8-500-1300 \mathrm{~m}(\mathrm{fb}, \mathrm{sb}, \mathrm{gb})-$ stones $-\mathrm{S}+$.

*Bucklandiella sudetica (Funck) Bednarek-Ochyra \& Ochyra - sp - K: 4; O: 8 - 200-1470 m (fb, sb, gb) - rock outcrops, stones along stream banks $-\mathrm{S}+$.

Buxbaumia aphylla Hedw. - r - *K: 4; O: 8-50-1100 m $(\mathrm{fb}, \mathrm{sb})$ - eroded soil along roads, naked peat on bogs $-\mathrm{S}+$.

*Callialaria curvicaulis (Jur.) Ochyra - un - K: 4 Vicinity Yagodnoye Settlement, Debin River $\left(62^{\circ} 28^{\prime} 04^{\prime \prime} \mathrm{N}\right.$ $\left.149^{\circ} 47^{\prime} 40^{\prime \prime} \mathrm{E}\right), 445 \mathrm{~m}$ alt., schist outcrops along the bank 3.VIII.2014] \{NSK\}.
Calliergon cordifolium (Hedw.) Kindb. - sp - K; O wetlands, floodplains (Blagodatskikh 1984).

Calliergon giganteum (Schimp.) Kindb. - r - K; O - wetlands, floodplains (Blagodatskikh 1984).

*Calliergon megalophyllum Mikut. - $\mathrm{r}-\mathrm{K}$ (Chemeris \& Mochalova 2015); OK (Chemeris \& Mochalova 2015) - (fb) - wetlands, floodplains.

Calliergon richardsonii (Mitt.) Kindb. $-\mathrm{r}-\mathrm{K}$; OK: 6; O -300-1100 m (fb, sb, gb) - wetlands, stream banks.

Calliergonella cuspidata (Hedw.) Loeske - un - O (River Ola close to Gadlya Settlement, floodplain, Blagodatskikh 1984).

Calliergonella lindbergii (Mitt.) Hedenäs $-\mathrm{sp}-\mathrm{K}$ : 2; OK: 6; O: 8-0-1200 m (fb, sb, gb) - floodplains, stream banks.

Campylium stellatum (Hedw.) C.E.O. Jensen $-\mathrm{sp}-* \mathrm{~K}$ (Sinelnikova 2009): 1, 2, 4; OK: 6; O: 7 - 300-1460 m (fb, $\mathrm{sb}, \mathrm{gb}$ ) - wetlands, floodplains, wet tundra, wet crevices on rock outcrops, stream banks.

*Campylophyllopsis sommerfeltii (Myrin) Ochyra - r K: 2 - $500 \mathrm{~m}$ (fb) - floodplains.

Catoscopium nigritum (Hedw.) Brid. - r - K: 2 - 300 $600 \mathrm{~m}(\mathrm{fb})$ - wet limestone - S+.

Ceratodon purpureus (Hedw.) Brid. - com - K (Sinelnikova 2009): 1, 2, 3, 4; OK: 5, 6; O: 7, 8; GO - 0-1600 m $(\mathrm{fb}, \mathrm{sb}, \mathrm{gb})$ - wetlands, floodplains, rock outcrops, stream banks, forests and shrub thickets, eroded substrate $-\mathrm{S}+$.

Cinclidium arcticum (Bruch et Schimp.) Schimp. $-\mathrm{r}-$ K: 1, 2, 4; *OK: 5, 6 - 300-1200 m (fb, gb) - wet Kobresia tundra, wet crevices on limestone outcrops.

Cinclidium latifolium Lindb. - un - O (Dukcha River) floodplain (Blagodatskikh 1984).

*Cinclidium stygium Sw. - r - OK: 6 - 1000-1200 m (gb) - wetlands.

Cinclidium subrotundum Lindb. - r - *OK: 6; O - 600$1200 \mathrm{~m}$ (sb, gb) - wetland, wet Kobresia tundra, stream bank.

Climacium dendroides (Hedw.) F. Weber \& D. Mohr - r OK: 5; O - 10-900 m (fb) - floodplains, crooked Betula forests.

Cnestrum schistii (F. Weber \& D.Mohr) I. Hagen - un K (Kulu and Sibit-Tyehllakh surroundings, between stones, Blagodatskikh 1984)

Conostomum tetragonum (Hedw.) Lindb. - sp - K: 1, 4; OK: 5, 6; O: 7, 8 - (10) 1000-1600 m (gb) - tundra, nival habitats, niche among rock fields $-\mathrm{S}+$.

*Coscinodon hartzii C.E.O. Jensen - r - K: 4-400-600 m (fb) - boulders on open sunny slope $-\mathrm{S}+$.

*Coscinodon yukonensis Hastings $-\mathrm{r}-\mathrm{K}$ (Cherdantseva \& Bakalin 2011): 3, 4; OK: 6 - 500-1220 m (fb, sb, gb) - on boulders $-\mathrm{S}+$.

*Cratoneuron filicinum (Hedw.) Spruce $-\mathrm{r}-\mathrm{K}$ : 2; OK: 6 - 350-1460 m (fb, sb, gb) - streams and springs.

* Cynodontium asperifolium (Lindb. \& Arnell) Paris - r - some specimens from the same locality OK: $\mathbf{6}-1300$ $1400 \mathrm{~m}(\mathrm{gb})$ - eroded soil in tundra, fine soil inbetween stones $-\mathrm{S}+$.

Cynodontium strumiferum (Hedw.) Lindb. - com - K: 2, 4; *OK: 6; O: 7, 8 - 350-1450 m (fb, sb, gb) - fine soil between stones on rock outcrops and rock fields, eroded substrate in Larix forests and tundra - S+.

Cynodontium tenellum (Schimp.) Limpr. - sp - K: 2, 4; OK: 6; O: 8 - 300-1100 m (fb, sb, gb) - fine soil on rock outcrops and rock fields, on spots in tundra $-\mathrm{S}+$.

Cyrtomnium hymenophylloides (Huebener) T.J. Kop. - sp - K: 1, 2; *OK: 5, 6 - 350-1200 m (fb, sb, gb) - rock outcrops.

*Cyrtomnium bymenophyllum (Bruch et Schimp.) Holmen - r - K: 1, 2; OK: 5, 6 - 340-1200 m (fb, sb, gb) - 
Duschekia fruticosa thickets, open Larix forest, tundra, crevices on rock outcrops.

Dicranella cerviculata (Hedw.) Schimp. - r - K; O: 8 $0-600 \mathrm{~m}(\mathrm{fb}, \mathrm{sb})$ - eroded substrates in different conditions - S+.

Dicranella crispa (Hedw.) Schimp. - r - K: 2, 4 - 150$450 \mathrm{~m}(\mathrm{fb})$ - floodplains, eroded substrates along streams and routes $-\mathrm{S}+$.

Dicranella grevilleana (Brid.) Schimp. - un - K (Omchak pass, stream banks, Blagodatskikh 1984).

*Dicranella schreberiana (Hedw.) Hilf. ex H.A. Crum $\boldsymbol{\&}$ L.E. Anderson - un - K (Seimchan River, roadside in the basin, $513 \mathrm{~m}$, Cherdantseva \& Bakalin 2011) \{VLA\}.

Dicranella subulata (Hedw.) Schimp. - sp - K: 4; O: 8 300-1500 m (fb, sb, gb) - eroded soil and peat in different surrounding $-\mathrm{S}+$.

*Dicranella varia (Hedw.) Schimp. - un - OK [Ola Distr, Chelomdga River middle course, along the river bank 28.VI.1982 coll. Blagodatskikh] \{IBIW, NSR \} - S+.

*Dicranum acutifolium (Lindb. \& Arnell) C.E.O. Jensen - r - K: 1, 4; OK: 6 - 1000-1300 m (gb) - tundra, niche among rock fields.

Dicranum bardunovii Tubanova \& Ignatova - r - K: 2; OK: 6 - 900-1300 m (gb) - tundra, open slope, stream bank.

Dicranum bonjeanii De Not. - r - *OK: 6; O - 100$1100 \mathrm{~m}$ (fb, sb, gb) - wetlands.

Dicranum elongatum Schleich. ex Schwägr. - com - K: (Sinelnikova 2009), 1-4; OK: 5, 6; O: 7, 8; G - 0-1460 m (fb, sb, gb) - Larix forests, Duschekia fruticosa thickets, Pinus pumila thickets, tundra, niche among rock fields.

Dicranum flexicaule Brid. - sp - K: 1, 4; OK: 6; O: 8 - 300-1300 m (fb, sb, gb) - Larix forests, tundra, niche among rock fields.

Dicranum fragilifolium Lindb. $-\mathrm{r}-\mathrm{K}$ : 1, 2; O (Ignatova \& Fedosov 2008) - 0-800 m (fb, sb) - floodplains.

*Dicranum fuscescens Turner $-\mathrm{r}-\mathrm{K}$ : 4; O: 8-400-900 m (fb) - Pinus pumila and Duschekia fruticosa thickets, bog.

Dicranum groenlandicum Brid. - sp - K: 1, 4; OK: 6; O: $8-0-1100 \mathrm{~m}$ (fb, sb, gb) - Larix forests, crooked Betula forests, bog, wet tundra and gravelly, rock fields.

*Dicranum laevidens R.S. Williams - r - K: 3, 4 - 400_ $900 \mathrm{~m}(\mathrm{fb})$ - Betula exilis bushes, bogs.

*Dicranum leioneuron Kindb. - un - K: 4 [B. Annachag Ridge, close to Jack London Lake (62 $\left.66^{\prime} 46^{\prime \prime} \mathrm{N} 149^{\circ} 28^{\prime} 58^{\prime \prime} \mathrm{E}\right)$, $990 \mathrm{~m}$ alt., wet draft-schrrb tundra 26.VII.2014] \{NSK\}.

Dicranum majus Turner - sp - K (Sinelnikova 2009); OK; O: 8; GO - 100-500 m (fb) - floodplains, Larix forests, Duschekia fruticosa thickets.

Dicranum montanum Hedw. - r - *K: 2; O - 100-200 m (fb) - floodplains.

Dicranum mueblenbeckii Bruch et Schimp. - un - O (Snezhnaya Dolina Settlement vicinity, rocky slopes, Blagodatskikh 1984).

Dicranum polysetum Sw. - r - O (some points, Larix forests, crooked Betula forests, Pinus pumila and Duschekia fruticosa thickets, Blagodatskikh 1984).

Dicranum scoparium Hedw. - r - *K: 4; O - 100-1200 m $(\mathrm{fb}, \mathrm{gb})$ - crooked Betula forest, crevices on rock outcrops.

Dicranum spadiceum J.E. Zetterst. - sp - K: (Sinelnikova 2009), 1, 4; OK: 6; O - 1000-1500 m (gb) - tundra, rock fields and outcrops.

Dicranum undulatum Schrad. ex Brid. - sp - K: 3, 4; OK: 6; O - 500-1200 m (fb, sb) - wetlands, wet Larix forests and Betula exilis shrubs.
*Didymodon asperifolius (Mitt.) H.A. Crum, Steere \& L.E. Anderson - un - OK: 6 [Olskoye Basalt Plateau, watershed of rivers Ola and B. Haya $\left(60^{\circ} 38^{\prime} 40^{\prime \prime} \mathrm{N}\right.$ $\left.151^{\circ} 26^{\prime} 34^{\prime \prime} \mathrm{E}\right), 1220 \mathrm{~m}$ alt, wet tundra near snowbed close to saddle, 6.VIII.2014] \{NSK\}.

*Didymodon ferrugineus (Schimp. ex Besch.) M.O. Hill - un - K: 2 [Magadansky State Nature Reserve, Zamkovaya Mt. area $\left(63^{\circ} 19^{\circ} 06^{\prime \prime} \mathrm{N} 152^{\circ} 35^{\prime} 00^{\prime \prime E}\right) 340 \mathrm{~m}$ alt., limestone 31.VII.2011 coll. Malashkina] \{VGBI, NSK\}.

Dilutineuron fasciculare (Hedw.) Bednarek-Ochyra, Sawicki, Ochyra, Szczecińska \& Plášek - r - O: 8 0-400 m (fb) - stream banks.

Distichium capillaceum (Hedw.) Bruch et Schimp. - sp - K: 1, 2; OK: 6; O: 7, 8 - 0-1400 m (fb, sb, gb) - fine soil between stones on rock outcrops and rock fields, eroded substrate in Larix forests and tundra - S+.

*Distichium hagenii Ryan ex H. Philib. - r-K: 1; OK: 6 1100-1300 m (gb) - crevices on rock outcrops - S+.

*Distichium inclinatum (Hedw.) Bruch et Schimp. un - OK: 6 [Olskoye Basalt Plateau, Skif Mt. $\left(60^{\circ} 39^{\prime} 10^{\prime \prime} \mathrm{N}\right.$ $\left.151^{\circ} 22^{\prime} 47^{\prime \prime} \mathrm{E}\right), 1460 \mathrm{~m}$ alt., rocky steep slope in tundra belt, in crevices of boulders, 7.VIII.2014] \{NSK\} - S+.

*Ditrichum cylindricum (Hedw.) Grout - un - K: 4 [vicinity Yagodnoye Settlement, slope to Debin River $\left(62^{\circ} 28^{\circ} 4^{\prime \prime} \mathrm{N}\right.$ $\left.149^{\circ} 47^{\circ} 41^{\prime \prime E}\right), 520 \mathrm{~m}$ alt., in a niche between stones on stone field in forest belt, 3.VIII.2014] $\{\mathrm{NSK}\}-\mathrm{S}+$.

Ditrichum heteromallum (Hedw.) E. Britton - r - *K: 1; *OK: 6; O: 8 - 300-1460 m (fb, sb, gb) - crevices on rock outcrops, eroded substrates $-\mathrm{S}+$.

*Ditrichum pusillum (Hedw.) Hampe - un - K: 4 [vicinity of Yagodnoye Settlement, Debin River $\left(62^{\circ} 28^{\prime} 04^{\prime \prime} \mathrm{N}\right.$ $\left.149^{\circ} 47^{\prime} 40^{\prime \prime} \mathrm{E}\right), 445 \mathrm{~m}$ alt., schist outcrops along the bank 3.VIII.2014] \{NSK\} - S+; O: 8 [Magadan City surroundings, Nagayev Bay area $\left(59^{\circ} 34^{\prime} \mathrm{N} 150^{\circ} 39^{\prime} \mathrm{E}\right), 330 \mathrm{~m}$ alt., sandstone cliffs near waterfall 05.VIII.2011 coll. Malashkina] \{VGBI, $\mathrm{NSK}\}-\mathrm{S}+$.

*Ditrichum zonatum (Brid.) Kindb. - un - K: 4 [B. Annachag Ridge, small lake in high-mountain cirques $\left(62^{\circ} 10^{\prime} 35^{\prime \prime} \mathrm{N}\right.$ $\left.149^{\circ} 19^{\prime} 59 \mathrm{9} \mathrm{E}\right), 1400 \mathrm{~m}$ alt., fine soil between stones 29.VII.2014] \{NSK\}.

Drepanocladus aduncus (Hedw.) Warnst. - sp - K: (Chemeris \& Mochalova 2015), 2, 4; *OK: 6; O - 300-1460 m - floodplains, wetlands.

Drepanocladus polygamus (Schimp.) Hedenäs - un - K (close to Nelkoba Settlement, Larix forest on a slope, Blagodatskikh 1984).

Drepanocladus sendtneri (Schimp. ex Müll. Hal.) Warnst. - un - K (close to Sibit-Tyehllakh Settlement, wetlands, Blagodatskikh 1984).

Echinophyllum sachalinense (Lindb.) O`Brian - un - O (Luzhin Bay, Duschekia fruticosa thickets in a stream valley, Blagodatskikh 1984).

*Encalypta affinis R. Hedw. - un - K (cliffs in Kolyma River valley $\sim 300 \mathrm{~m}$, Chemeris \& Mochalova 2015) $\{\mathrm{IBIW}$.

*Encalypta alpina Sm. - un - OK: 6 [Olskoye Basalt Plateau, upper course of Ola River, small stream in Pinus pumila-alnus belt $\left(60^{\circ} 39^{\prime} 00.7^{\prime \prime} \mathrm{N} 151^{\circ} 24^{\prime} 58.4^{\prime \prime} \mathrm{E}\right), 1200 \mathrm{~m}$ alt. 09.VIII.2011 coll. Malashkina, det. Cherdantseva] \{VBGI\}.

*Encalypta brevicollis Ångstr. - sp - K: (Fedosov 2012), 1, 4; OK: 5, 6; O: 7 - 800-1460 m (sb, gb) - crevices on rock outcrops $-\mathrm{S}+$.

*Encalypta brevipes Schljakov - r - OK: 5, 6 - 1200 $1400 \mathrm{~m}$ (gb) - crevices on rock outcrops, soil in dry gravelly tundra $-\mathrm{S}+$.

Encalypta ciliata Hedw. - sp - K: 2; *OK: 6; *O: 8 10-1200 m (fb, sb, gb) - rock outcrops $-\mathrm{S}+$. 
Encalypta procera Bruch - r - K: 1, 2; *OK: 6 - 530$1600 \mathrm{~m}$ (fb, sb, sb) - crevices on rock outcrops.

Encalypta rhaptocarpa Schwägr. - sp - K: 1, 2, 4; *OK: 6; O: 7, 8-10-1600 m (fb, sb, gb) - crevices on rock outcrops, soil in dry gravelly tundra - S+.

*Encalypta trachymitria Ripart - un - OK: 6 [Olskoye Basalt Plateau, Skif Mt. (60³9'10"N 151²2'47"E), $1460 \mathrm{~m}$ alt., in crevices of boulder on rocky steep slope in tundra belt, 7.VIII.2014] $\{$ NSK $\}-$ S + .

*Entodon concinnus (De Not.) Paris - un - K: 2 [Upper course of Kolyma River, Magadansky State Nature Reserve,

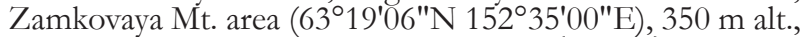
limestone 31.VII.2011 coll. Malashkina] \{VBGI\}.

Eurhynchiastrum pulchellum (Hedw.) Ignatov \& Huttunen $-\mathrm{r}-{ }^{*} \mathrm{~K}: 2$; OK: 6; O: 8 - 300-1300 m (fb, sb, gb) - floodplains, rock outcrops, tundra.

* Fissidens adianthoides Hedw. - un - OK: 6 [Olskove Basalt Plateau, watershed of rivers Ola and B. Hava $\left(60^{\circ} 38^{\prime} 42^{\prime \prime} \mathrm{N}\right.$ $\left.151^{\circ} 29^{\prime} 15^{\prime E} \mathrm{E}\right), 1090 \mathrm{~m}$ alt, saddle between tops, boggy KobresiaEriophorum tundra 5.VIII.2014 coll. Bakalin] \{NSK $\}-$ S+.

*Fissidens bryoides Hedw. - r - K: (Malashkina 2012), 1; OK: 6 - 600-1460 m (sb, gb) - fine soil in different conditions $-\mathrm{S}+$.

*Fissidens osmundoides Hedw. - r - K: 1; OK: (Cherdantseva \& Bakalin 2011), 5, 6 - 800-1200 m (sb, gb) - Pinus pumila thickets, tundra, rock outcrops, nival habitats.

Flexitrichum flexicaule (Schwägr.) Ignatov \& Fedosov (Ditrichum flexicaule (Schwägr.) Hampe) - sp - K: (Chemeris \& Mochalova 2015), 1, 2, 4; OK: 5, 6; O, GO - 0-1600 m $(\mathrm{fb}, \mathrm{sb}, \mathrm{gb})$ - fine soil and naked peat in Larix forests, Pinus pumila thickets, Betula exilis shrubs, tundra, crevices on rock outcrops and niche among rock fields $-\mathrm{S}+$.

*Flexitrichum gracile (Mitt.) Ignatov \& Fedosov (= Ditrichum gracile (Mitt.) Kuntze) - r - K: 2; OK: 6 - 300-1200 m $(\mathrm{fb}, \mathrm{sb}, \mathrm{gb})$ - crevices on rock outcrops.

Fontinalis antipyretica Hedw. - r - OK - in streams.

*Fontinalis antipyretica Hedw. var. gracilis (Lindb.) Shimp. - r - O (Chemeris \& Mochalova 2015) - in streams and rivers.

Funaria hygrometrica Hedw. - r - K; O - 0-300 m (fb) eroded substrates in different conditions $-\mathrm{S}+$.

* Grimmia alpestris (F. Weber \& D. Mohr) Schleich. un - O: 8 [Magadan vicinity, Marchekanskava hill, N-faced slope in lower part $\left(59^{\circ} 31^{\prime} 42^{\prime \prime} \mathrm{N} 150^{\circ} 49^{\prime} 05^{\prime \prime E}\right), 240 \mathrm{~m}$ alt., Duschekia fruticosa thickets along a stream, on stones 10.VIII.2014] $\{\mathrm{NSK}\}-\mathrm{S}+$.

* Grimmia donniana Sm. - sp - K: (Ignatova \& Munoz 2004), 4; OK: 5, 6 - 500-1400 m (fb, sb, gb) - on stones - S+.

* Grimmia elatior Bruch ex Bals.-Criv. \& De Not. un - K: 1 [Tuonnakh Mt. Range, Verina River upstream $\left(63^{\circ} 17^{\prime} 31^{\prime \prime} \mathrm{N} 151^{\circ} 25^{\prime} 29^{\prime \prime} \mathrm{E}\right) 1300 \mathrm{~m}$ alt., stones near stream 23.VIII.2011 coll. Malashkina] \{VBGI\}.

* Grimmia funalis (Schwägr.) Bruch et Schimp. - r - K: 2; OK: 6 - 1000-1300 m (gb) - stones - S+.

Grimmia incurva Schwägr. - r - K: (Ignatova \& Munoz 2004), 4; *O: 7 - 1000-1300 m (gb) - crevices in rock outcrops and niche among rock fields.

* Grimmia jacutica Ignatova, Bednarek-Ochyra, Afonina \& Muñoz - un - K: 4 Vicinity Yagodnoye Settlement, slope to Debin River (62 $\left.26^{\prime} 44^{\prime \prime N} 149^{\circ} 49^{\prime} 01^{\prime \prime E}\right), 520 \mathrm{~m}$ alt., on boulders of a stone field in forest belt, 3.VIII.2014 \{NSK\}.

Grimmia longirostris Hook. - com - K: (Ignatova \& Munoz 2004), 1, 4, *OK: 6 - 520-1460 m (fb, sb, gb) - on stones in different conditions $-\mathrm{S}+$.

Grimmia mollis Bruch et Schimp. - com - K: (Ignatova \& Munoz 2004), 1, 4; OK; O: (Ignatova \& Munoz 2004), 8 - 0-1400 m (fb, sb, gb) - streams - S+.
*Grimmia reflexidens Müll. Hal. - sp - K: 1, 4; OK: 6; O: 7, 8-200-1400 m (fb, sb, gb) - on stones - S+.

* Grimmia torquata Drumm. - r - K: 4; OK: 6 - 1200$1600 \mathrm{~m}$ (fb, sb, gb) - rock outcrops.

*Gymnostomum aeruginosum Sm. - r - K: 1, 2 - 300$1200 \mathrm{~m}$ (fb, sb, gb) - limestone.

Hamatocaulis lapponicus (Norrl.) Hedenäs - un - K (Detrin River valley close to Ust-Omchug, Blagodatskikh 1984); [Bilibino Distr., Omolon River $5 \mathrm{~km}$ upstream Kedon mouth $\left(\sim 65^{\circ} 38^{\prime} \mathrm{N} 159^{\circ} 29^{\prime} \mathrm{E}\right), \sim 500 \mathrm{~m}$ alt., water of small lake between mire 2.VII.1976 Antropova] $\{M A G\}$.

*Hamatocaulis vernicosus (Mitt.) Hedenäs - un - K [Susuman Distr., Adigalakh Settlement vicinity $\left(62^{\circ} 55^{\prime} 23^{\prime \prime} \mathrm{N}\right.$ $\left.146^{\circ} 20^{\prime} 24^{\prime \prime E}\right), 700 \mathrm{~m}$ alt., Eriophorum-Sphagnum bog in river valley. 04.VIII.1960 coll.\&det. Dobretsova] $\{$ SASY\}.

Helodium blandowii (F. Weber \& D. Mohr) Warnst. - r - K: 4; O - 0-750 m (fb) - wetlands, stream banks.

Herzogiella adscendens (Lindb.) Z. Iwats. \& W.B. Schofield - r - O: 8 - 0-200 m (fb) - crooked Betula forests.

Hygroamblystegium humile (P. Beauv.) Vanderp. Goffinet \& Hedenäs $-\mathrm{r}-{ }^{*} \mathrm{~K}: 2$; O: 8 - 0-500 m (fb) - floodplains, wetlands, stream banks.

Hygroamblystegium varium (Hedw.) Mönk. - r - O: 8 0-300 m (fb) - floodplains.

Hygrohypnella ochracea (Turner ex Wilson) Ignatov \& Ignatova - sp - K: (Czernyadjeva 2004), 1, 4; *OK: 6; *O: 8 - 100-900 m (fb, sb) - streams.

Hygrohypnella polare (Lindb.) Ignatov \& Ignatova com - K: (Czernyadjeva 2004), 1, 4; OK: 6; O -0-1500 m $(\mathrm{fb}, \mathrm{sb}, \mathrm{gb})$ - streams.

Hylocomiastrum pyrenaicum (Spruce) M. Fleisch. - r *K: 4; O: 7, 8 - 0-1470 m (fb, sb, gb) - crooked Betula forests, Duschekia fruticosa thickets, stream banks, rock outcrops.

Hylocomium splendens (Hedw.) Schimp. - com - K: 1, 2, 4; OK: 6; O: 8; GO - 340-1300 m (fb, sb, gb) - Larix forests, Duschekia fruticosa thickets, Betula exilis shrubs, tundra, wetlands.

Hymenoloma crispulum (Hedw.) Ochyra - com - K: 1, 4; OK: 5, 6; O: 7, 8-0-1500 m (fb, sb, gb) - on stones - S+.

*Hymenostylium recurvirostrum (Hedw.) Dixon - un - K: 2 Uupper course of Kolyma River, Magadansky State Nature Reserve, Zamkovaya Mt. area (631ำ06.6"N 152 35'00.2"E), $350 \mathrm{~m}$ alt., limestone crevices 31.VII.2011 coll. Malashkina] $\{$ VBGI, NSK\}.

Hypnum cupressiforme Hedw. - sp - K: (Sinelnikova 2009), 2; OK: 6; O; GO - 350-1460 m (fb, sb, gb) - rock outcrops and rock fields, open grassy slopes, steppe, tundra.

Hypnum imponens Hedw. - un - K (Vicinity Kulu Settlement, Blagodatskikh 1984); O (Luzhin Bay slope, Blagodatskikh 1984). The records are doubtful (Ignatov et al. 2006).

*Hypnum saitoi Ando - un - $\mathbf{K}$ (vicinity Sibit-Tyehllakh Settlement, $\sim 600 \mathrm{~m}\{\mathrm{LE}\}$, Afonina \& Blagodatskikh 2006); OK: [Olskoye Basalt Plateau, Maltan River $\left(60^{\circ} 39^{\prime} 33^{\prime \prime N}\right.$ $151^{\circ} 21^{\prime} 27^{\prime E}$ ), $1190 \mathrm{~m}$, cliffs 07.VIII.2011 coll. Malashkina, det. Cherdantseva] \{VBGI\}.

*Isopterygiopsis alpicola (Lindb. \& Arnell) Hedenäs un - K: 4 Vicinity Yagodnoye Settlement, slope to Debin River, $\left(62^{\circ} 09^{\prime} 01^{\prime \prime N} 149^{\circ} 22^{\prime} 09^{\prime \prime} \mathrm{E}\right), 520 \mathrm{~m}$ alt., in a niche between stones on stone field in forest belt, 3.VIII.2014] $\{$ NSK\}; O: 8 [Magadan vicinity, Okhotsk coast, Nagaeva Bay $\left(59^{\circ} 34^{\prime} 14^{\prime \prime} \mathrm{N} 150^{\circ} 38^{\prime} 32^{\prime \prime} \mathrm{E}\right), 16 \mathrm{~m}$ alt., in crevices of coastal rocks, 10.VIII.2014] \{NSK\}.

*Isopterygiopsis muelleriana (Schimp.) Z. Iwats. - r - K: 4; O: 8-300-1300 m (fb, sb, gb) - niche among rock fields. Isopterygiopsis pulchella (Hedw.) Z. Iwats. - sp - K: 4; *OK: 6; O: 7, 8-250-1460 m (fb, sb, gb) - Larix forests, Duschekia fruticosa thickets, crooked Betula forests, stream banks, rock outcrops and fields, nival habitats $-\mathrm{S}+$. 
Iwatsukiella leucotricha (Mitt.) W.R. Buck \& H.A. Crum - un - K (close to Sibit-Tyehllakh Settlement, on Betula trunks, Blagodatskikh 1984); O (Luzhin Bay slope, on Betulatrunks, Blagodatskikh 1984).

Kiaeria blyttii (Bruch et Schimp.) Broth. - r - K; O: 8 300-1200 m (sb, gb) - stream banks, tundra, nival habitats - S+.

Kiaeria glacialis (Berggr.) I. Hagen - r - K; O: 8 - 300$1200 \mathrm{~m}$ (sb, gb) - stream banks, tundra, nival habitats.

Leptobryum pyriforme (Hedw.) Wilson - sp - K: 1, 2, 4; *OK: 6; O - 0-1450 m (fb, sb, gb) - floodplains, open grassy slopes, crevices in rock outcrops and naked substrates in different conditions $-\mathrm{S}+$.

*Leptodictyum riparium (Hedw.) Warnst. - un - O (Lankovaya River, in water, Chemeris \& Mochalova 2015) \{IBIW\}.

Lescuraea radicosa (Mitt.) Mönk. - r - *OK: 6; O - 100$1300 \mathrm{~m}$ (fb, sb, gb) - rock outcrops and rock fields, tundra.

*Lewinskya iwatsukii (Ignatov) F. Lara, Garilleti \& Goffinet (Orthotrichum iwatsukii) - r - K: 4; OK: 5, 6-900$1500 \mathrm{~m}(\mathrm{sb}, \mathrm{gb})$ - on stones.

Lewinskya pylaisii (Brid.) F. Lara, Garilleti \& Goffinet (Orthotrichum pylaisii Brid.) - r - OK; O (On stones (Blagodatskikh 1984).

Lewinskya sordida (Sull. \& Lesq.) F. Lara, Garilleti \& Goffinet (Orthotrichum sordidum Sull. \& Lesq.) - r - OK: 6; O: 8 - 0-1400 m (fb, sb, gb) - floodplains, crooked Betula forests, rock fields $-\mathrm{S}+$.

Loeskypnum badium (Hartm.) H.K.G. Paul - r - K: 1, 4; OK: 6; O - 1000-1100 m (gb) - wet tundra, stream banks and and wet niche among rock fields.

Lyellia aspera (I. Hagen \& C.E.O. Jensen) Frye - r K (Ivanova \& Ignatov 2007); OK (Pisarenko et al. 2015) $600-1000 \mathrm{~m}(\mathrm{fb}, \mathrm{sb}, \mathrm{gb})$ - fine soil in rock crevices and ledges among open Larix forests and tundra $-\mathrm{S}+$.

*Meesia longiseta Hedw. - un - OK: 6 [Olskoye Basalt Plateau, upper course of Ola River $\left(60^{\circ} 41^{\prime} 24^{\prime \prime} \mathrm{N} 151^{\circ} 13^{\prime} 48^{\prime \prime} \mathrm{E}\right)$ $1090 \mathrm{~m}$ alt., swampy tundra. 12.VIII.2011 coll. Malashkina] (Pisarenko et al. 2015).

Meesia triquetra (Jolycl.) Ångstr. - r - *K: 1; *OK: 6; O - 800-1200 m (fb, sb, gb) - wetlands.

Meesia uliginosa Hedw. - sp - K: 1, 2; *OK: 5, 6; O $300-1200 \mathrm{~m}(\mathrm{gb})$ - wetlands, stream banks and and wet crevices on limestone outcrops $-\mathrm{S}+$.

*Mielichboferia mielichboferiana (Funck) Loeske - un - K: 4 [B. Annachag Ridge, upper part of E-facing macro slope $\left(62^{\circ} 10^{\prime} 01^{\prime \prime} \mathrm{N} 149^{\circ} 18^{\prime} 17^{\prime \prime} \mathrm{E}\right), 1600 \mathrm{~m}$ alt., in a niche between granite boulders on periphery of summer-persisting snow patch, 29.VII.2014] \{NSK\}.

*Mnium blyttii Bruch et Schimp. - un - K: 4 B. Annachag Ridge, upper part of E-macro slope (62¹0'26"N $\left.149^{\circ} 18^{\prime} 50^{\prime \prime} \mathrm{E}\right)$, $1470 \mathrm{~m}$ alt., in a niche between granite boulders on periphery of summer-persisting snow patch, 29.VII.2014] \{NSK\}.

Mnium lycopodioides Schwägr. - r - K: 4; O - 100-1200 m (fb, sb, gb) - stream banks, crooked Betula forests, tundra.

Mnium marginatum (Dicks.) P. Beauv. - r - *K: 2; OK; O -100-500 m (fb) - Larix forest, open grassy slope, limestone.

Mnium thomsonii Schimp. - r - *OK: 6; O - 100-1100 m (fb, sb, gb) - crooked Betula forests, Duschekia fruticosa thickets, tundra.

Myurella julacea (Schwägr.) Schimp. - r - K: 1, 2; OK: 5, 6; O: 8 - 10-1500 m (fb, sb, gb) - rock outcrops.

*Myurella sibirica (Müll. Hal.) Reimers - un - K: 2 [Upper course of Kolyma River, Magadansky State Nature Reserve,

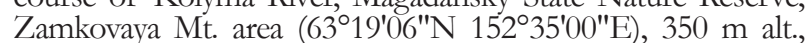
limestone, admixture to Cyrtomnium bymenophylloides and Philonotis tomentella 31.VII.2011 coll. Malashkina] $\{$ VBGI $\}$.
Myurella tenerrima (Brid.) Lindb. - r - K: 2; *OK: 6 350-1300 m (fb, sb, gb) - limestone, strean banks, tundra.

*Myuroclada longiramea (Müll. Hal.) Min Li, Y.F. Wang, Ignatov \& Huttunen - r - O: (Chemeris \& Mochalova 2015), 8 - 10-300 m (fb) - floodplains, stream banks, Duschekia fruticosa thickets.

Myuroclada maximowiczii (G.G. Borshch.) Steere \& W.B. Schofield - r - O: 8 - 0-300 m (fb) - crooked Betula forests, Duschekia fruticosa thickets, wet shaded rock outcrops.

Neckera pennata Hedw. - r - K; *OK: 6 - 600-1400 m $(\mathrm{fb}, \mathrm{sb}, \mathrm{gb})$ - niche among rock fields.

Niphotrichum canescens (Hedw.) Bednarek-Ochyra \& Ochyra - com - K: (Sinelnikova 2009), 1, 4; OK: 6; O - 500$1600 \mathrm{~m}$ (fb, sb, gb) - floodplains, Duschekia fruticosa and Pinus pumila thickets, tundra, stream banks, rock fields and outctops.

Niphotrichum ericoides (Brid.) Bednarek-Ochyra \& Ochyra (Racomitrium canescens var. strictum) - $\mathrm{r}-\mathrm{K}$ : 4; OK; O; GO - 800-1400 m (sb, gb) - stream banks, rock outcrops, tundra.

*Niphotrichum panschii (Müll.Hal.) Bednarek-Ochyra \& Ochyra - r - OK: 6 - 1100-1460 m (gb) - tundra, rock fields.

*Oedipodium griffithianum (Dicks.) Schwägr. - un - O: 7 [Kemennii Ridge (59 48'24"N 149 40'30"E), 900 m alt., cliffs on the watershed, crevices undo rock 7.VIII.2013 coll. \& det. Bakalin] \{VGBI\}.

*Oligotrichum falcatum Steere - sp - K: 1, 4; O: 7, 8 - 600-1600 m (sb, gb) - fine soil between stones on rock outcrops and fields, on open slopes.

Oligotrichum parallelum (Mitt.) Kindb. $-\mathrm{r}-* \mathrm{~K}$ : 4; O: 8-200-1400 m (sb, gb) - Duschekia fruticosa thickets, Betula exilis bushes, fine soil between stones along stream banks, on rock fields and tundra.

*Oncophorus virens (Hedw.) Brid. - sp - K: 2; OK: 6; O: 8-300-1400 m (fb, sb, gb) - floodplains, stream banks.

Oncophorus wablenbergii Brid. - sp - K: 2, 4; OK: 6; O: $8-500-1200 \mathrm{~m}$ (fb, sb, gb) - floodplains, crooked Betula forests, Duschekia fruticosa thickets, Larix forest, tundra, stream banks $-\mathrm{S}+$.

Orthothecium chryseon (Schwägr.) Schimp. - r - K: 1, 2; *OK: 6 - 300-1600 m (fb, sb, gb) - rock fields, stream banks, wet rock outcrops and niche among rock fields.

Orthothecium strictum Lorentz - r - K: 1, 2 - 350-1300 m (fb, sb, gb) - stream banks.

*Orthotrichum anomalum Hedw. - un-K: 2 [Magadansky State Nature Reserve, Zamkovaya Mt. area (63819'06"N $\left.152^{\circ} 35^{\prime} 00^{\prime \prime E}\right), 340 \mathrm{~m}$ alt., limestone 31.VII.2011 coll. Malashkina] $\{\mathrm{VGBI}\}-\mathrm{S}+$.

*Orthotrichum pellucidum Lindb. - un - K [Korkodon River, Kidley Ridge, 22.VII.2002 coll. Mochaloval (Fedosov \& Ignatova 2011).

Oxystegus tenuirostris (Hook. \& Tayl.) A.J.E. Sm. $-\mathrm{r}-\mathrm{K}$ : 1, 2; *OK: 6; *O: 8 - 300-1300 m (fb, sb, gb) - rock outcrops.

Paludella squarrosa (Hedw.) Brid. - sp - *K: 4; OK: 5, 6; O: 7, 8-100-1100 m (fb, sb) - wetlands, stream banks, aufeis places.

Paraleucobryum longifolium (Hedw.) Loeske - r - O (Pinus pumila thickets, stream banks, Blagodatskikh 1984).

Philonotis fontana (Hedw.) Brid. - sp - K: 1, 4; *OK: 6; O: 8 - 10-1600 m (fb, sb, gb) - wetlands, stream banks - S+.

Philonotis tomentella Molendo - sp - K: (Chemeris \& Mochalova 2015), 2, 4; *OK: 6; O - 350-1300 m (fb, sb, $\mathrm{gb})$ - stream banks and wetlands.

Plagiomnium curvatulum (Lindb.) Schljakov $-\mathrm{r}-\mathrm{K}$ : 2, 4; O-100-800 m (fb, sb) - floodplains, stream banks - S+.

Plagiomnium cuspidatum (Hedw.) T.J. Kop. - un - O [Ola Distr, Chelomdga River middle course, floodplain fo- 
rest of Larix, Betula and Populus, on rotten wood. 24.VI.1982 Blagodatskikh] \{LE\}.

Plagiomnium ellipticum (Brid.) T.J. Kop. - sp - K: 1, 2, 4; *OK: 6; O - 350-1460 m (fb, sb, gb) - floodplains, wetlands, stream banks, wet niche among rock fields.

Plagiomnium medium (Bruch et Schimp.) T.J. Kop. r - K: 2; *OK: 6 - 350-900 m (fb) - open grassy slopes, stream banks.

* Plagiopus oederianus (Sw.) H.A. Crum \& L.E. Anderson - r-K: 2; OK: $\mathbf{6}-300-900 \mathrm{~m}$ (fb) - crevices on rock outcrops; mainly on limestones $-\mathrm{S}+$.

*Plagiothecium berggrenianum Frisvoll - r - O: 7 - 300$900 \mathrm{~m}$ (fb, sb, gb) - crevices on rock outcrops.

Plagiothecium cavifolium (Brid.) Z. Iwats. - r - *OK: 6; O: 8 - 0-900 m (fb, sb) - rock outcrops.

Plagiothecium denticulatum (Hedw.) Schimp. - com *K: 2, 4; *OK: 6; O: 8 - 200-1300 m (fb, sb, gb) - Betula forests, Duschekia fruticosa and Pinus pumila thickets, floodplains, stream banks and wetlands, open grassy slopes, rock outcrops, nival habitats $-\mathrm{S}+$.

*Plagiothecium euryphyllum (Cardot \& Thér.) Z. Iwats. - un - O: 8 [Magadan vicinity, Marchekanskava hill, N-slope in lower part $\left(59^{\circ} 31^{\prime} 42^{\prime \prime} \mathrm{N} 150^{\circ} 49^{\prime} 05^{\prime \prime} \mathrm{E}\right), 240 \mathrm{~m}$ alt., in moss cover in Duschekia fruticosa thickets along stream, 10.VIII.2014] \{NSK\}.

Plagiothecium laetum Schimp. - com - K: 2, 4; OK: 6; O 7, 8; GO - 0-1200 m (fb, sb, gb) - Larix forests, crooked Betula forests, Duschekia fruticosa thickets, wetlands, stream banks, rock outcrops, open grassy slopes $-\mathrm{S}+$.

*Plagiothecium latebricola Schimp. - un - O: 8 [Magadan city surroundings, Okhotsk coast, Kamennyi venets Mt. $\left(59^{\circ} 31^{\prime} 13^{\prime \prime} \mathrm{N} 150^{\circ} 40^{\prime} 17^{\prime \prime} \mathrm{E}\right) 300 \mathrm{~m}$ alt, Duschekia fruticosa thickets on the slope, on trunks 13.VIII.2013 coll. Ermolenko] \{NSK\}.

* Platydictya jungermannioides (Brid.) H.A. Crum un - OK: 6 [Olskoye Basalt Plateau, Skif Mt. $\left(60^{\circ} 38^{\prime} 39^{\prime \prime} \mathrm{N}\right.$ $\left.151^{\circ} 22^{\prime} 14^{\prime \prime E}\right), 1460 \mathrm{~m}$ alt., steep slope, cliffs close to the top, in crevices 7.VIII.2014] \{NSK\}.

* Platyhypnum alpestre (Hedw.) Ochyra - r - OK: 6; O: (Chemeris \& Mochalova 2015), 7, 8-300-1100 m (fb, sb, $\mathrm{gb}$ - wetlands, wet tundra and rock outcrops.

* Platyhypnum cochlearifoliun (Venturi) Ochyra - un - K: 4 [B. Annachag Ridge, upper part of E-macroslope $\left(62^{\circ} 09^{\prime} 36^{\prime \prime N} 149^{\circ} 22^{\prime} 39^{\prime \prime} \mathrm{E}\right), 1150 \mathrm{~m}$ alt., on granite boulders along a stream in tundra belt, 30.VII.2014] \{NSK\}; OK: 6 [Olskoye Basalt Plateau; Maltan Riverin upper course $\left(60^{\circ} 39^{\prime} 33^{\prime \prime} \mathrm{N} 151^{\circ} 21^{\prime} 27^{\prime \prime E}\right), 1190 \mathrm{~m}$ alt., cliffs 08.VIII.2011 coll. Malashkina, det. Cherdantseva] \{VBGI\}.

* Platyhypnum duriusculum (De Not.) Ochyra - un - O: 8 Magadan city surroundings, Okhotsk coast, slope to Nagaeva Bay (59 34'12.8"N 150³8'31.7"E), $290 \mathrm{~m}$ alt., stones along the stream 05.VIII.2011 coll. Malashkina] \{NSK\}.

* Platyhypnum mollie (Dicks ex Hedw.) Ochyra - un reported by Blagodatskikh samples for $\mathbf{K}$ (along a stream vicinity Kulu Settlement, Czernyadjeva 2004) \{LE\}.

*Platyhypnum norvegicum (Schimp.) Ochyra - r - K: (Czernyadjeva 2004), 4; OK: 6 - 600-1200 m (sb, gb) stream banks.

Pleurozium schreberi (Brid.) Mitt. - com - K: 4; OK: 5, 6; O: 7, 8; GO - 100-1600 m (fb, sb, gb) - floodplains, wetlands, Larix forests, Duschekia fruticosa thickets, Pinus pumila thickets, tundra stream banks, niches among rock fields.

Pogonatum dentatum (Brid.) Brid. - sp - K: 1, 4; OK: 6; O: 8; GO - 400-1300 m (fb, sb, gb) - eroded soil along roads, stream banks, between stones on rock outcrops and rock fields $-\mathrm{S}+$.

Pogonatum urnigerum (Hedw.) P. Beauv. - sp - K: 4; *OK: 6; O - 0-1600 m (fb, sb) - rock fields, stream banks, nival habitats $-\mathrm{S}+$
Poblia andalusica (Höhn.) Broth. - un - K (Vicinity Kulu Settlement, Blagodatskikh 1984, as P. rothii); O (Czernyadjeva 1999, by Blagodatskikh specimens) $\{\mathrm{LE}\}$.

Pohlia andrewsii A.J. Shaw - r - *K: 4; OK: (Czernyadjeva 1999), 6; *O: 8 - 0-1400 m (fb, sb, gb) - eroded substrates in different conditions.

Poblia annotina (Hedw.) Lindb. - r - K; O: 8 - 10$500 \mathrm{~m}(\mathrm{fb})$ - eroded substrates in different conditions.

*Poblia atropurpurea (Wahlenb.) H. Lindb. - r - K: 4 1100-1600 m (gb) - niche among rock fields - S+.

*Pohlia beringiensis A.J. Shaw - r - K: (Czernyadjeva 1999), 4 - 440-1300 m (fb, sb, gb) - cryoturbation spots in tundra and eroded soil along roads.

Poblia bulbifera (Warnst.) Warnst. - r - K: 4; OK (Czernyadjeva 1999) - $500 \mathrm{~m}(\mathrm{Fb})$ - floodplains, eroded soil along streams.

Poblia cruda (Hedw.) Lindb. - com - K: 2, 4; OK: 5, 6; O: 7, 8; GO - 300-900 m (fb, sb) - wetlands, Larix forests, Duschekia fruticosa thickets, crevices in rock fields, stream banks $-\mathrm{S}+$.

Poblia crudoides (Sull. \& Lesq.) Broth. - com - K: 1, 2, 4; *OK: 6; O: 8 - 300-1300 m (fb, sb, gb) - wetlands, rock outcrops and rock fields, stream banks, tundra, nival habitats $-\mathrm{S}+$.

Poblia drummondii (Müll. Hal.) A.L. Andrews - sp - K: 4; OK: 6 - 1200-1600 m (gb) - niche among rock fields, nival habitats.

*Poblia elongata Hedw. - r - K: 4; O: 8-300-500 m (fb) - crevices on rock outcrops $-\mathrm{S}+$.

*Poblia filum (Schimp.) Martensson-un-K: 4 [B. Annachag Ridge, close to Jack London Lake (62 $\left.{ }^{\circ} 23^{\prime \prime} \mathrm{N} 149^{\circ} 29^{\prime} 59^{\prime \prime} \mathrm{E}\right)$, $1100 \mathrm{~m}$ alt., fine soil between granite boulders along a stream, in admixture with Poblia atropurpurea 26.VII.2014] \{NSK\}.

Pohlia longicollis (Hedw.) Lindb. - r - K: 1 - 500-1600 m (fb, sb, gb) - Pinus pumila thickets, stream banks, rock outcrops.

Poblia nutans (Hedw.) Lindb. - sp - K: 1, 4; *OK: 6; O: 7, 8 - 100-1400 m (fb, sb, gb) - stream banks, rock outcrops, wetlands, Larix forests, tundra $-\mathrm{S}+$.

Poblia proligera (Kindb.) Lindb. ex Broth. $-\mathrm{r}-* \mathrm{~K}: 2$, 4; O (Czernyadjeva 1999) - 400-550 m (fb) - eroded substrates in different conditions.

Poblia wablenbergii (F. Weber \& D. Mohr) A.L. Andrews - sp - K: 1, 2, 4; O: 8 - 250-1600 m (fb, sb, gb) wetlands, stream banks, springs, aufeis places, nival habitats.

Polytrichastrum alpinum (Hedw.) G.L. Sm. - sp - K: (Ivanova et al. 2014), 1, 2, 4; OK: 6; O: 7, 8; G - 250$1600 \mathrm{~m}$ (fb, sb, gb) - crooked Betula forests, Duschekia fruticosa thickets, tundra, nival habitats, wetlands, rock fields - S+.

Polytrichastrum fragile (Bryhn) Schljakov - r - K; O (Ivanova et al. 2014) - open grassy slopes, stream banks.

*Polytrichastrum septentrionale (Brid.) E.I. Ivanova, N.E. Bell \& Ignatov - r - K: 4; O: 7 - 1000-1600 m (gb) - fine soil near snowbed - S+.

Polytrichastrum sexangulare (Florke ex Brid.) G.L. Sm. - r - K; O: 8 - $1000(\mathrm{fb}, \mathrm{sb}, \mathrm{gb})$ - nival habitats in shaded ravine slopes.

*Polytrichastrum sphaerothecium (Besch.) J.-P. Frahm un - O: 8 Magadan vicinity, Nagaeva Bay coast, Vodopadnyj Stream $\left(59^{\circ} 34^{\prime} 14^{\prime \prime} \mathrm{N} 150^{\circ} 38^{\prime} 32^{\prime \prime} \mathrm{E}\right), 330 \mathrm{~m}$ alt., in crevices of rock outcrops along the stream, 10.VIII.2014] $\{$ NSK $\}-$ S + .

Polytrichum commune Hedw. - sp - K: (Sinelnikova 2009), 4; OK; O; GO - 500-1500 m (fb, sb, gb) - floodplains, Larix forest, tundra, wetlands.

Polytrichum hyperboreum R. Br. - r - K: 4; O-800-1200 m (fb, sb, gb) - crooked Betula forests, Pinus pumila thickets, tundra.

Polytrichum jensenii I. Hagen - r - K: 2; O - 300-1300 m $(\mathrm{fb}, \mathrm{sb}, \mathrm{gb})$ - wetlands, Betula exilis bushes, wet tundra. 
Polytrichum juniperinum Hedw. - com - K: (Sinelnikova 2009), 1, 4; OK; O: 8 - 500-1400 m (fb, sb, gb) - Larix forests, Betula exilis bushes, tundra, rock fields.

*Polytrichum longisetum Sw. ex Brid. - r - some Blagodatskikh samples from K (close to Sibit-Tyehllakh Settlement); O (close to Snezhnaya Dolina Settlement and Chelomdga River) \{LE $\}$ - Larix forests, stream banks.

Polytrichum piliferum Hedw. - sp - K: (Sinelnikova 2009), 1, 2, 4; OK:, 6; O: 7; GO - 500-1600 m (fb, sb, gb) - floodplains, Larix forests, open grassy slopes, rock outcrops, tundra.

Polytrichum strictum Brid. - sp - K: 2, 4; OK: 5, 6; O: 8; GO - 100-1300 m (fb, sb, gb) - bogs, Larix forests, tundra.

*Polytrichum swartzii Hartm. - un - K /Vicinity of Kulu Settlement $\left(\sim 61^{\circ} \mathrm{N} 147^{\circ} \mathrm{E}\right)$, swampy Larix forest 6.VII.1974 Blagodatskikh] \{MAG, NSK\}; OK: 5 [Dyugadyak and Kilgana Rivers watershed $\left(61^{\circ} 11^{\prime} 43^{\prime \prime} \mathrm{N} 153^{\circ} 55^{\prime} 56^{\prime \prime} \mathrm{E}\right) 900 \mathrm{~m}$ alt., ridge-hollow mire complex along lake shore 8.VIII.2012 coll. Ermolenko] $\{\mathrm{VGBI}\}$.

Pseudobryum cinclidioides (Huebener) T.J. Kop. - $\mathrm{r}-$ OK; O - (fb, sb) - Larix forests, Duschekia fruticosa thickets, floodplains, wetlands.

*Pseudocalliergon brevifolium (Lindb.) Hedenäs - un OK: 6 [Olskove Basalt Plateau, watershed of rivers Ola and B. Haya $\left(60^{\circ} 38^{\prime} 41.71^{\prime \prime N} 151^{\circ} 29^{\prime} 15,29^{\prime \prime E}\right) 1090 \mathrm{~m}$ alt., saddle between tops, boggy Kobresia-Eriophorum tundra 5.VIII.2014] $\{\mathrm{NSK}\}$.

Pseudocalliergon trifarium (F. Weber \& D. Mohr) Loeske - un - O (Atargan vicinity, mire, Blagodatskikh 1984).

*Pseudobygrobypnum subeugyrium (Renauld \& Cardot) Ignatov \& Ignatova - un - K [Vicinity Sibit-Tyehllakh Settlement, along a stream, 23.VII.1976 coll. Blagodatskikh] (Czernyadjeva 2004) $\{\mathrm{LE}\}$.

Pseudoleskeella nervosa (Brid.) Nyholm - r - *K: 2; O 100-300 m (fb) - floodplains, limestone.

Pseudoleskeella papillosa (Lindb.) Kindb. - $\mathrm{r}-$ *OK: 6; O - 100-1400 m (fb, sb, gb) - crooked Betula forests, niche among rock fields.

*Pseudoleskeella rupestris (Berggr.) Hedenäs \& L. Söderstr. - r - K: 1, 2 - 350-1300 m (fb, sb, gb) - limestone.

Pseudoleskeella tectorum (Funck ex Brid.) Kindb. ex Broth. - un - O (close to Balagannoe, floodplain, Blagodatskikh 1984).

Pseudotaxiphyllum elegans (Brid.) Z. Iwats. - un - O (Spafarev Island, on rocky slopes, Blagodatskikh 1984).

Psilopilum cavifolium (Wilson) I. Hagen [BLAG] - r $\mathbf{K}\{\mathrm{LE}\}-\mathrm{fb}$ - eroded soil near winter frazil place $-\mathrm{S}+$.

Psilopilum laevigatum (Wahlenb.) Lindb. [BLAG] - r $\mathbf{K} ; \mathbf{O}$ - eroded soil along streams; some Blagodatskikh collections $\{M A G, L E\}-S+$.

*Pterigynandrum filiforme Hedw. - un - K: 4 [B. Annachag Ridge, upper part of E-macroslope $\left(62^{\circ} 10^{\prime} 23^{\prime \prime} \mathrm{N} 149^{\circ} 20^{\prime} 21^{\prime \prime E}\right)$, $1300 \mathrm{~m}$ alt., on granite boulders on a place of long-persisting snow patch in tundra belt, 29.VII.2014] \{NSK\}.

Ptilium crista-castrensis (Hedw.) De Not. - sp - K: 2; *OK: 5, 6; O - 0-1100 m (fb, sb, gb) - Larix forests, Duschekia fruticosa thickets, Pinus pumila thickets, tundra.

Pylaisia polyantha (Hedw.) Schimp. - sp - K; *OK: 6; O: 8 - 50-1100 m (fb, sb) - floodplains - S+.

Pylaisia selwynii Kindb. - r - O: 8 - 50-200 m (fb) floodplains $-\mathrm{S}+$.

Racomitrium lanuginosum (Hedw.) Brid. - com - K: (Sinelnikova 2009), 1, 4; OK: 5, 6; O: 7, 8 - 1000-1600 m $(\mathrm{sb}, \mathrm{gb})$ - tundra, rock fields.

Rhabdoweisia crispata (Dicks. ex With.) Lindb. - r - K: 4; O: 7, 8-0-500 $\mathrm{m}(\mathrm{fb})$ - rock outcrops $-\mathrm{S}+$.
Rhizomnium andrewsianum (Steere) T.J. Kop. - sp - K: 1, 4; OK: 5, 6; O - 0-1200 m (fb, sb, gb) - Larix forests, Duschekia fruticosa thickets, tundra, rock outcrops, stream banks.

*Rhizomnium gracile T.J. Kop. - un - K: 4 [B. Annachag Ridge, Sukhakhy River, terrace $\left(62^{\circ} 12^{\prime} 44^{\prime \prime} \mathrm{N} 149^{\circ} 29^{\prime} 09^{\prime \prime E}\right)$, $880 \mathrm{~m}$ alt., in moss cover of mesotrophic mire in forest belt, 27.VII.2014] \{NSK\}.

Rhizomnium magnifolium (Horik.) T.J. Kop. - r - O: $8-0-500 \mathrm{~m}(\mathrm{fb})$ - floodplains, stream banks, Duschekia fruticosa thickets.

Rhizomnium nudum (E. Britton \& R.S. Williams) T.J. Kop. - r - O: 8-100-600 $\mathrm{m}(\mathrm{fb})$ - stream valleys, on soil in Duschekia fruticosa thickets, stream banks and at the cliffs bottom.

Rhizomnium pseudopunctatum (Bruch et Schimp.) T.J. Kop. $-\mathrm{r}-{ }^{*} \mathrm{~K}:$ 4; *OK: 6; O: 8-0-1200 m (fb, sb, gb) wetlands, stream banks and springs $-\mathrm{S}+$.

Rhodobryum roseum (Hedw.) Limpr. - un - O (Spafarev Island, on rocky slopes, Blagodatskikh 1984).

Rhytidiadelphus subpinnatus (Lindb.) T.J. Kop. - r - O: $8-0-500 \mathrm{~m}$ (fb) - crooked Betula forests, Duschekia fruticosa thickets, stream banks.

Rhytidiadelphus triquetrus (Hedw.) Warnst. - r - O crooked Betula forests, Duschekia fruticosa thickets.

Rhytidium rugosum (Hedw.) Kindb. - com - K: 1, 2, 4; OK: 6; O: 7 - 0-1600 m (fb, sb, gb) - floodplains, dry Larix forests, open grassy slopes and steppe, rock outcrops and rock fields, tundra.

Saelania glaucescens (Hedw.) Broth. $-\mathrm{r}-\mathrm{K}$ : 4; OK: 5, 6; $\mathbf{O}-900-1300 \mathrm{~m}$ (sb, gb) - crevices on rock outcrops.

Sanionia uncinata (Hedw.) Loeske - com - K: 1, 2, 4; OK: 6; O: 7, 8; GO - 800-1600 m (fb, sb, gb) - floodplains, wetlands Larix forests, Duschekia fruticosa thickets, Pinus pumila thickets, tundra, rock outcrops.

Schistidium agassizii Sull. \& Lesq. - r - K: (Chemeris \& Mochalova 2015), 4; *O (Chemeris \& Mochalova 2015) 500-1100 m (fb, sb, gb) - stones in and along streams - S+.

*Schistidium crenatum $\mathrm{H}$.H. Blom - un - K /Vicinity SibitTyehllakh Settlement, 25.VIII.1977 coll. Blagodatskikh, det. Ignatova] \{MW (http://arctoa.ru/Flora/basa.php).

*Schistidium frigidum H.H. Blom - r - K: 4; OK: 6 1000-1600 m (gb) - on stones - S+.

*Schistidium liliputanum (Müll. Hal.) Deguchi - r - K: 4; O: 8 - 300-500 m (fb) - rock outcrops - S+.

*Schistidium papillosum Culm. - sp - K: 1, 2, 4; OK: 6; O: 7 - 350-1460 m (fb, sb, gb) - on stones - S+.

*Schistidium platyphyllum (Mitt.) Perss. - sp - K: 1, 4; OK: 6 - 900-1400 m (sb, gb) - streams - S+.

*Schistidium pulchrum H.H. Blom - un - OK: 6 [Olskoye Basalt Plateau, Skif Mt. $\left(60^{\circ} 38^{\prime} \mathrm{N} 151^{\circ} 22^{\prime} \mathrm{E}\right)$, $1460 \mathrm{~m}$ alt., cliffs near the top 7.VIII.2014 coll. Pisarenko, det. Ignatova] (Pisarenko et al. 2015) - S+.

Schistidium rivulare (Brid.) Podp. - sp - K: 1, 2, 4; O: 8 - 300-1400 m (fb, sb, gb) - streams - S+.

*Schistidium sordidum I. Hagen - un - K: 4 [B. Annachag Ridge, Sukhakhi River valley (62¹1'59"N 149²9'12"E), $840 \mathrm{~m}$ alt., stones on the river bank 25.VII.2014] \{NSK\} - S+; OK' [Gusakova pass 19.VII.1972 coll. Blagodatskikh, det. Ignatova] \{MW\} (http://arctoa.ru/Flora/basa.php).

*Schistidium tenerum (J.E. Zetterst.) Nyholm - un - OK: 6 [Olskoye Basalt Plateau, Skif Mt., steep E-faced slope $\left(60^{\circ} 38^{\prime} 39.88^{\prime \prime} \mathrm{N} 151^{\circ} 22^{\prime} 14.52^{\prime \prime} \mathrm{E}\right), 1460 \mathrm{~m}$ alt., cliffs near the top. 7.VIII.2014 coll. Pisarenko, det. Ignatova] \{NSK, MW\}$\mathrm{S}+$.

*Schistidium tenuinerve Ignatova \& H.H. Blom - un OK: 6 [Olskoye Basalt Plateau, watershed of rivers Ola and 
B. Haya $\left(60^{\circ} 38^{\prime} 40^{\prime \prime} \mathrm{N} 151^{\circ} 26^{\prime} 34^{\prime \prime E}\right), 1220 \mathrm{~m}$ alt., wet tundra near snowbed 6.VIII.2014 coll. Pisarenko, det. Ignatova] $\{\mathrm{NSK}, \mathrm{MW}\}-\mathrm{S}+$.

Schistostega pennata (Hedw.) F. Weber \& D. Mohr - r - OK; $\mathbf{O}$ - in floodplains on fine soil along stream, near Larix roots and in rock crevises.

Sciuro-bypnum latifolium (Kindb.) Ignatov \& Huttunen - r - *K: 2; *OK: 6; O (Ignatov \& Milytina 2007): 8 - 100 $1100 \mathrm{~m}$ (fb, sb) - Duschekia fruticosa thickets, stream banks.

*Sciuro-hypnum plumosum (Hedw.) Ignatov \& Huttunen - un - O: 8 [Magadan city surroundings, Okhotsk coast, Nagaev Bay (59॰34'12.8"N 150³8'31.7"E), $290 \mathrm{~m}$ alt., Sphagnum bog on a watershed, on peat 10.VIII.2014] \{NSK\}.

Sciuro-hypnum reflexum (Starke) Ignatov \& Huttunen - sp - *OK: 6; O: 8 - 300-1100 m (fb, sb) - Betula forests, Duschekia fruticosa and Pinus pumila thickets, floodplains, stream banks and wetlands $-\mathrm{S}+$.

*Sciuro-hypnum starkei (Brid.) Ignatov \& Huttunen - un - O: 8 [Magadan vicinity, Marchekanskaya hill, N-faced slope in lower part $\left(59^{\circ} 31^{\prime} 42^{\prime \prime} \mathrm{N} 150^{\circ} 49^{\prime} 05^{\prime \prime} \mathrm{E}\right), 240 \mathrm{~m}$ alt., Duschekia fruticosa thickets along stream, on soil 10.VIII.2014] \{NSK\}.

Scorpidium cossonii (Schimp.) Hedenäs $-\mathrm{r}-\mathrm{K}$; *OK: 6; O - 900-1100 m (fb, sb, gb) - wetlands.

Scorpidium revolvens (Sw. ex anon.) Rubers $-\mathrm{r}-\mathrm{K} 4$; OK 6; O - 900-1400 m (fb, sb, gb) - wetlands.

Scorpidium scorpioides (Hedw.) Limpr. - r - *K (Sinelnikova 2009, Chemeris \& Mochalova 2015); O - 0-800 m - in lakes and wetland.

Scouleria pulcherrima Broth. - r - K: (Chemeris \& Mochalova 2015), 2-300-500 $\mathrm{m}$ - in streams and rivers.

Seligeria diversifolia Lindb. (earlier was reported as $S$. cam pylopoda, Pisarenko 2015) - un - K: 4 B. Annachag Ridge, Sukhakhy River $\left(62^{\circ} 06^{\prime} 46^{\prime N} \mathrm{~N} 149^{\circ} 28^{\circ} 56^{\prime \prime E}\right), 990 \mathrm{~m}$ alt., in crevices of granite boulder on stone field in forest belt, 25.VII.2014 coll. Pisarenko, det. Fedosov\} \{NSK, MW\}-S+.

*Sphagnum alaskense R.E. Andrus \& Janssens - sp - K: (Maksimov \& Ignatova 2008), 1, $4-400-1300$ m (fb, sb, $\mathrm{gb})$ - bogs and tundra.

Sphagnum angustifolium (C.E.O. Jensen ex Russow) C.E.O. Jensen - r - *K: (Sinelnikova 2009), 4; OK: 6; O 300-1200 m (fb, sb, gb) - bogs and wet tundra.

Sphagnum aongstroemii Hartm. - com - K: (Sinelnikova 2009), 4; OK: 6; O - 400-1200 m (fb, sb, gb) - wetlands, wet Larix forests and tundra, aufeis places.

Sphagnum balticum (Russow) C.E.O. Jensen - r - K: 1 , 4; *O: 8 - 500-1300 m (fb, sb, gb) - wetlands.

Sphagnum beringiense A.J. Shaw, R.E. Andrus \& B. Shaw - un - K Detrin River floodplain 24.VII.1972 coll. Blagodat skikh] \{LE\} (Maksimov et al. 2016).

Sphagnum capillifolium (Ehrh.) Hedw. $-\mathrm{r}-* \mathrm{~K}$ : (Sinelnikova 2009), 1, 4; O - 300-1300 m (fb, sb) - wetlands, wet Larix forests and tundra, stream banks.

Sphagnum compactum Lam. \& DC. - sp - K: (Sinelnikova 2009), 1, 2, 4; OK; O - 800-1300 m (sb, gb) - wetlands, Betula exilis bushes, wet tundra, stream banks, nival habitats.

Sphagnum contortum Schultz - r - K: 4; *OK: 6; O 0-1200 m (fb, sb, gb) - wetlands.

Sphagnum cuspidatum Ehrh. ex Hoffm. $-\mathrm{r}-\mathrm{K}$ (in moss cover of mires and wet Larix forests, Blagodatskikh 1984).

Sphagnum fimbriatum Wilson - r-K: (Sinelnikova 2009), 4; O - 0-1000 m (fb, sb, gb) - wetlands, aufeis places, wet tundra.

*Sphagnum flexuosum Dozy \& Molk. - r - K: 4 - 450$900 \mathrm{~m}(\mathrm{fb})$ - wetlands.

Sphagnum fuscum (Schimp.) H. Klinggr. - sp - K: (Sinelnikova 2009), 1, 4; O - 300-1100 m (tb, sb, gb) - bogs, wet Larix forests and tundra.
Sphagnum girgensobnii Russow - com - K: (Sinelnikova 2009) 1, 4; OK: 6; O: 8 - 0-1200 m (fb, sb, gb) - wetlands, wet Larix forests and tundra, Duschekia fruticosa thickets, stream banks.

Sphagnum lenense H. Lindb. ex L.I. Savicz - com - K: (Sinelnikova 2009), 1, 4; OK; O: 8 - 100-1300 m (fb, db, gb) - wet Larix forests and tundra, wet niche among rock fields.

Sphagnum lindbergii Schimp. ex Lindb. - com - K: (Sinelnikova 2009), 4; O: 8 - 300-1100 m (fb, sb, gb) - bogs, wet tundra, stream banks.

Sphagnum orientale L.I. Savicz - un - K (Sibit-Tyehllakh vicinity, in moss cover of wet open Larix forest and mountain tundra, Blagodatskikh 1984).

*Sphagnum papillosum Lindb. - un - O: 8 [Magadan city surroundings, Okhotsk coast, Nagaev Bay (59 34'13.8"N $\left.150^{\circ} 38^{\prime} 31.6^{\prime \prime} \mathrm{E}\right), 330 \mathrm{~m}$ alt., Sphagnum bog on watershed, 10.VIII.2014] \{NSK\}.

Sphagnum perfoliatum L.I. Savicz - un - K (Kulu vicinity, wet tundra, Blagodatskikh 1984); O: 8 [Magadan city surroundings, Okhotsk coast, Nagaev Bay (59 $34^{\prime} 13.8^{\prime \prime N}$ $\left.150^{\circ} 38^{\prime} 31.6^{\prime \prime E}\right), 330 \mathrm{~m}$ alt., Sphagnum bog on watershed, 10.VIII.2014] $\{\mathrm{NSK}\}$

*Sphagnum platyphyllum (Lindb. ex Braithw.) Warnst. - r- K: 4; OK: 6 - 900-1300 (gb) - stones along stream banks and near snowbeds $-\mathrm{S}+$.

*Sphagnum quinquefarium (Lindb. ex Braithw.) Warnst. - un - K: 4 [B. Annachag Ridge, the foot of E-faced slope $\left(62^{\circ} 12^{\prime} 04^{\prime \prime} \mathrm{N} 149^{\circ} 28^{\prime} 26^{\prime \prime} \mathrm{E}\right), 860 \mathrm{~m}$ alt., in moss cover oligotrophic Sphagnum bog with well-developed shrab layer (Vaccinium uliginosum, Ledum palustre, Andromeda polifolia) 25.VII.2014] \{NSK\}.

Sphagnum riparium Ångstr. - sp - *K: 4; O - 0-1100 m (fb, sb, gb) - wetlands, stream banks.

*Sphagnum rubellum Wilson - r- K: 1, 4; OK: (Cherdantseva \& Bakalin 2011), 6 - 500-1300 m (b, sb, gb) - Larix forests, Betula exilis shrubs, wet tundra.

*Sphagnum rubiginosum Flatberg - r - OK: 6 - 1100$1250 \mathrm{~m}(\mathrm{sb}, \mathrm{gb})$ - wet tundra.

Sphagnum russowii Warnst. - r - K: 1, 4; OK: 6; O 0-1300 m (fb, sb, gb) - wet Larix forests and tundra.

Sphagnum squarrosum Crome - sp - K (Sinelnikova 2009); OK: 6; O - 0-1200 m (fb, sb) - wetlands, streams and springs under canopy Larix forests, crooked Betula forests, Duschekia fruticosa thickets.

*Sphagnum steerei R.E. Andrus - r - K (Maksimov 2007); O (Maksimov 2007): 8 - 1-600 m (fb) - wetlands.

*Sphagnum subfulvum Sjörs - un - K: 1 B. Tuonnakh Mt. Range, Verina River upstream (631' $\left.31^{\prime \prime} \mathrm{N} 151^{\circ} 25^{\prime} 29^{\prime \prime} \mathrm{E}\right)$, $1300 \mathrm{~m}$ alt. on soil between stones near stream 23.VIII.2011 coll. Malashkina, det. Cherdantseva] \{VBGI, NSK\}.

*Sphagnum subsecundum Nees - un - K: 6 [Olskoye Basalt Plateau, watershed of rivers Ola and B. Haya $\left(60^{\circ} 38^{\prime} 33^{\prime \prime} \mathrm{N} 151^{\circ} 26^{\prime} 54^{\prime \prime E}\right) 1200 \mathrm{~m}$ alt., small stream on meadow slope, between stones 6.VIII.2014] \{NSK\}.

Sphagnum teres (Schimp.) Ångstr. - sp - K: 1, 4; *OK: 6; O - 800-1300 m (fb, sb, gb) - wetlands, stream banks.

*Sphagnum tundrae Flatberg - r - K: 4; OK: 6 - 900 $1300 \mathrm{~m}$ (fb, sb, gb) - wet open Larix forests with Sphagnum cover and wet tundra.

Sphagnum warnstorfi Russow - com - K: (Sinelnikova 2009), 1, 2, 4; OK: 6; O; G - 300-1300 m (fb, sb, gb) bogs, wet Larix forests and tundra.

Splachnum ampullaceum Hedw. - r - O (on soil in Betula forests, Blagodatskikh 1984).

Splachnum luteum Hedw. - r - K; OK; O (decomposed dung in Larix forests and crooked forests, Blagodatskikh 1984).

Splachnum rubrum Hedw. - r - K; OK; O (decomposed dung in Larix forests and crooked forests, Blagodatskikh 1984). 
Stereodon bambergeri (Schimp.) Lindb. - un - K (Omulevka River, limestone, Blagodatskikh 1984); *OK: 6 (Olskoye Basalt Plateau, watershed of rivers Ola and B. Haya $\left(60^{\circ} 38^{\prime} 42^{\prime \prime N} 151^{\circ} 29^{\prime} 15^{\prime \prime E}\right), 1090 \mathrm{~m}$ alt., saddle between tops, boggy Kobresia-Eriophorum tundra 5.VIII.2014] \{NSK\}.

*Stereodon holmenii (Ando) Ignatov \& Ignatova - r - K (Afonina 2004); OK (Afonina 2004).

Stereodon plicatulus Lindb. - com - K; OK: 6; O 8; G 0-1100 m (fb, sb, gb) - rock outcrops.

* Stereodon plumaeformis (Wilson) Mitt. - un - K (SibitTyehllakh, Afonina \& Ignatova 2007) $\{$ LE $\}$.

*Stereodon procerrimus (Molendo) Bauer - un - K: 2 [Upper course of Kolyma River, Magadansky State Nature

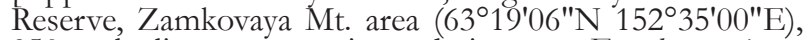
$350 \mathrm{~m}$ alt., limestone crevices, admixture to Entodon concinnus 31.VII.2011 coll. Malashkina] \{VBGI\}.

Stereodon revolutus Mitt. - r - K; *OK: 6 - 1200-1460 m (gb) - tundra, rock fields.

Stereodon subimponens (Lesq.) Broth. - sp - K; OK (open Larix forests, tundra, rock outcrops, Blagodatskikh 1984).

Stereodon vaucheri (Lesq.) Lindb. ex Broth. - r - K: 2 300-900 m (fb) - open grassy slope, dry tundra, on gravelly soil.

Straminergon stramineum (Dicks. ex Brid.) Hedenäs - com - K: (Sinelnikova 2009), 1, 4; OK: 6; O: 8; G 0-1300 m (fb, sb, gb) - wetlands, wet Larix forests, Duschekia fruticosa thickets and tundra, stream banks.

*Syntrichia norvegica F. Weber - un - OK: 6 [Olskoye Basalt Plateau, watershed of rivers Ola and B. Haya $\left(60^{\circ} 38^{\prime} 16^{\prime \prime} \mathrm{N} 151^{\circ} 29^{\prime} 17^{\prime \prime} \mathrm{E}\right), 930 \mathrm{~m}$ alt., on gravelly soil on S-faced meadow slope near tree-line, 8.VIII.2014] \{NSK\}.

Syntrichia ruralis (Hedw.) F. Weber \& D. Mohr - sp K: 1, 2, 4; *OK: 6-300-1460 m (fb, sb, gb) - open grassy slopes, rock outcrops and rock fields, dry tundra - S+.

*Tayloria lingulata (Dicks.) Lindb. - un - OK: 6 (Olskoye Basalt Plateau close to Skif Mt., $1050 \mathrm{~m}$, wet moss tundra, Cherdantseva \& Bakalin 2011) \{VLA\}; 5 Dyugadyak and Kilgana Rivers watershed (61 $\left.10^{\circ} 32^{\prime \prime N} 153^{\circ} 53^{\circ} 33^{\prime \prime E}\right)$, $886 \mathrm{~m}$, wet hollows near lake bank, 10.VIII.2012 coll. Ermolenko] $\{\mathrm{VBGI}$.

Tetraphis pellucida Hedw. - $\mathrm{r}-\mathrm{K}$; OK; O: 8 - 0-500 m (fb) - floodplains, Larix forests, Duschekia fruticosa thickets.

* Tetraplodon angustatus (Hedw.) Bruch et Schimp. - un - K: 4 [Vicinity Yagodnoye Settlement, Debin River valley $\left(62^{\circ} 28^{\prime} 04^{\prime \prime} \mathrm{N} 149^{\circ} 47^{\prime} 40^{\prime \prime} \mathrm{E}\right), 520 \mathrm{~m}$ alt., stone field among Larix forest, on animal remains 3.VIII.2014] $\{$ NSK $\}-$ S+.

Tetraplodon mnioides (Hedw.) Bruch et Schimp. - sp *K: 1, 4; OK: 6; O: 7 - 400-1300 m (fb, sb, gb) - decomposed animal remains among wetlands and tundra $-\mathrm{S}+$.

* Tetraplodon urceolatus (Hedw.) Bruch et Schimp. un - OK: $\mathbf{6}$ [Olskoye Basalt Plateau, near Yablonevy pass $\left(60^{\circ} 37^{\prime} 23^{\prime \prime} \mathrm{N} 151^{\circ} 33^{\prime} 57^{\prime \prime E}\right), 1180 \mathrm{~m}$ alt., on organic debris on talus in tundra belt, 9.VIII.2014] $\{$ NSK $\}-$ S+.

Thuidium assimile (Mitt.) A. Jaeger $-\mathrm{r}-* \mathrm{OK}$ : 6; O 300-1200 m (fb, sb, gb) - crooked Betula forests, thickets along streams, shades rocks.

Timmia austriaca Hedw. - r - K: 1, 2, 4-200-1300 m (fb, sb, gb) - rock outcrops, tundra, nival habitats.

*Timmia comata Lindb. et $\mathbf{H}$. Arnell - un - K (cliffs in Kolyma valley $\sim 300 \mathrm{~m}$, Chemeris \& Mochalova 2015) \{IBIW\}.

*Timmia sibirica Lindb. et H. Arnell - un - K: 2 [Upper course of Kolyma River, Magadansky State Nature Reserve,

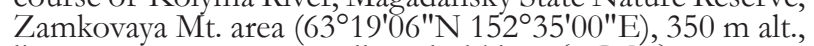
limestone 31.VII.2011 coll. Malashkina] \{VBGI\}.

Tomentypnum nitens (Hedw.) Loeske - com - K: (Sinelnikova 2009), 1, 2, 4; OK: 5, 6; O: 7, 8-300-1600 m (fb, $\mathrm{sb}, \mathrm{gb}$ ) - wetlands Larix forests, tundra.
*Tortella alpicola Dixon - un - O: 7 Kamennyy Khrebet Range, central part $\left(59^{\circ} 48^{\prime} 10^{\prime \prime} \mathrm{N} 149^{\circ} 39^{\prime} 45^{\prime \prime} \mathrm{E}\right), 1062 \mathrm{~m}$ alt., crevices on rock outcrops 8.VIII.2013 coll. Ermolenko] \{VGBI\}.

*Tortella arctica (Arnell) Crundw. \& Nyholm - r - OK: 6 [Olskoye Basalt Plateau, watershed of rivers Ola and B. Haya (60 38'42"N 151 $\left.29^{\circ} 17^{\prime} \mathrm{E}\right), 1090 \mathrm{~m}$ alt, between stones in wet Kobresia-Eriophorum tundra 5.VIII.2014] \{NSK\}; [Olskoye Basalt Plateau, watershed of rivers Ola and B. Haya (60³8'40"N 151 26'34"E), $1220 \mathrm{~m}$ alt, wet tundra near snowbed close to saddle, 6.VIII.2014] \{NSK\}.

Tortella fragilis (Hook.\& Wils.) Limpr. $-\mathrm{r}-\mathrm{K}$ : 1; OK: 6-300-1600 m (fb, sb, gb) - crevices on rock outcrops, soil in dry gravelly tundra.

Tortella tortuosa (Hedw.) Limpr. - r - K: 2; *OK: 6 300-1200 m (fb, sb, gb) - rock outcrops.

Tortula hoppeana (Schultz) Ochyra - r - *OK: 6; O: 7, $8-1000-1300 \mathrm{~m}(\mathrm{gb})$ - crevices on rock outcrops, eroded soil $-\mathrm{S}+$.

* Tortula laureri (Schultz) Lindb. - un - OK: 6 [Olskoye Basalt Plateau, Skif Mt. ( 60 38'40"N 151 $\left.{ }^{\circ} 22^{\prime} 15^{\prime \prime} \mathrm{E}\right), 1460$ $\mathrm{m}$ alt, steep slope close to the top, rock outcrops, in crevices 7.VIII.2014] \{NSK $\}-\mathrm{S}+$.

Tortula mucronifolia Schwägr. - r - K: 1, 2; *OK: 6; *O: 7 - 500-1460 m (fb, sb, gb) - crevices on rock outcrops, eroded substrates $-\mathrm{S}+$.

Trachycystis flagellaris (Sull. \& Lesq.) Lindb. - r - O: 7, 8 - 0-500 m (fb) - crooked Betula forests, Duschekia fruticosa thickets, stream banks, wet shaded rock outcrops.

*Trematodon ambiguus (Hedw.) Hornsch. - un - O: 8 [27 km west of Magadan, Oksa River valley ( 59 $39^{\circ} 07^{\prime \prime} \mathrm{N}$ $\left.150^{\circ} 29^{\prime} 09^{\prime \prime E}\right), 6 \mathrm{~m}$ alt, sandy bank of stream 17.VII.2011 coll. Malashkina] $\{\mathrm{NSK}, \mathrm{VBGI}\}-\mathrm{S}+$.

Ulota curvifolia (Wahlenb.) Lilj. - r - K: 4 - 300-500 m (fb) - rock outcrops.

Warnstorfia exannulata (Schimp.) Loeske - Cm - K: 4; *OK: 6; O: 8 - 0-1200 m (fb, sb, gb) - wetlands.

Warnstorfia fluitans (Hedw.) Loeske - com - K: 1, 4; O: 7 - 0-1100 m (fb, sb, gb) - wetlands - S+.

*Warnstorfia pseudosarmentosa (Cardot \& Thér.) Tuom. \& T.J. Kop. $-\mathrm{r}-$ K: 4; O: 8 - 300-1000 m (fb, sb, gb) wetlands, stream banks.

*Warnstorfia pseudostraminea (Müll. Hal.) Tuom. \& T.J. Kop. - r - K: 2, 4-500 m (fb) - floodplains.

Warnstorfia sarmentosa (Wahlenb.) Hedenäs - com - K: (Sinelnikova 2009), 1, 2, 4; *OK: 5, 6; O - 500-1400 m (fb, $\mathrm{sb}, \mathrm{gb}$ ) - wetlands, wet tundra, stream banks, nival habitats.

*Warnstorfia trichophylla (Warnst.) Tuom. \& T.J. Kop. - un - K: 4 B. Annachag Ridge, close to Jack London Lake $\left(62^{\circ} 8^{\prime} 23^{\prime \prime} \mathrm{N} 149^{\circ} 29^{\prime} 59^{\prime \prime E}\right), 1100 \mathrm{~m}$ alt., stream bank 26.VII.2014] $\{$ NSK $\}$.

\section{Species excluded}

Aloina brevirostris (Hook. \& Grev.) Kindb. - the only record (Blagodatskikh 1984) based on misidentification of A. rigida $\{\mathrm{LE}\}$.

Brachythecium salebrosum (F. Weber \& D. Mohr) Schimp. - it was reported for the Okhotsk floristic district: vicinity Snezhnaya Dolina Settlement; Kolyma floristic district: vicinity Sibit-Tyehllakh Settlement (Blagodatskikh 1984). During the genus revision (Ignatov 2012), no samples from the northern Far East were confirmed for exception of some from Kamchatka Peninsula.

Coscinodon cribrosus (Hedw.) Spruce - so-named specimen from Sibit-Tyehllakh vicinity (Blagodatskikh 1984) was re-identified for C. yukonensis.

Dicranum angustum Lindb. - was reported as common species (Blagodatskikh 1984); but according to the latest revision 
(Ignatova 2005) the species is rare in Russia and was not revealed in Nothern Far East, most so-identified samples belong to $D$. laevidens.

Lescuraea mutabilis (Brid.) Lindb. - according Ignatov \& al. (2006) the records of the species eastward of the Urals are doubtful.

Oligotrichum bercynicum (Hedw.) Lam. \& DC. - the reports by Blagodatskikh (1984) based on O. falcatum (Ivanova et al. 2005).

Orthotrichum speciosum Nees (Lewinskya speciosa (Nees) F. Lara, Garilleti \& Goffinet) according to recent revision (Fedosov \& Doroshina 2018) does not occur in Asian Russia. All checked specimens belong to L. iwatsukii.

Schistidium apocarpum (Hedw.) Bruch et Schimp. - all sonamed Russian Far East specimens belong to other taxa (Ignatov, Afonina, Ignatova et al. 2006).

Schistidium confertum (Funck) Bruch et Schimp. - excluded from the flora of the Russian Far East; all so-named specimens belong to other species (Ignatova \& Blom 2017).

Schistidium strictum (Turner) Loeske ex Martensson excluded from moss flora of Russia (Ignatov \& al. 2006).

Sphagnum imbricatum Hornsch. ex Russow - it was reported for the Kolyma floristic district: vicinity Sibit-Tyehllakh Settlement (Blagodatskikh 1984), however, the cited specimens belong to S. steerei (Maksimov 2007).

Trichostomum arcticum Kaal. - it was reported for the Okhotsk floristic district: Atargan and Kolymsky floristic district: Omulevka River (Blagodatskikh 1984). The first sample is checked, it is Oxystegus tenuirostre $\{\mathrm{LE}\}$. The second report is doubtful (specimen was not found), therefore the occurrence of the species in Magadan needs additional confirmation.

\section{CONCLUDING REMARKS}

It is worth noting that we regard the present checklist to be preliminary only, since most of the Magadan Province remains poorly investigated, specifically in the the eastern part of the province. Data on the Omolonsky and the Gizhigsky floristic districts are completely absent, while data on Gizhigsko-Omolonsky district is poor. However, in comparison with the previous checklist by Blagodatskikh (1984), the number of recorded taxa has increased by some $30 \%$. Currently we list 364 moss taxa.

For many genera, the increase in known taxa is the result of taxonomic revisions. For instance, the known diversity of Bryum was increased from 4 to 16 species due to Zolotov's (2018) revision, of which 11 taxa were treated by the monographer (B. algovicum, B. amblyodon, B. archangelicum, B. bimum, B. creberrimum, B. cyclophyllum, B. intermedium, B. knowltonii, B. longisetum, B. pseudotriquetrum and B. salinum). Bryum argenteum, B. caespiticium, B. cryophilum, B. purpurascens and B. weigelii were previously known from the area. Another example is in the Grimmiaceae where the efforts by Ignatova (Ignatova \& Blom 2017, Ignatova \& Muñoz 2004) increased the diversity of Schistidium with the addition of $S$. frigidum, $S$. holmenianum, $S$. liliputanum, S. papillosum, S. pulbrum, S. platyphyllum and S. sordidum; as well as the diversity of Grimmia from 3 to 8 species $(G$. donniana, G. jacutica, G. pilifera, G. reflexidens and $G$. torquata added). Due to recent taxonomic revisions of herbarium specimens (Ignatova 2005, Tubanova et al. 2010, Tubanova \& Ignatova 2011) Dicranum is expanded with the addition of D. acutifolium, D. bardunovii, D. laevidens and D. leioneuron. A similar situation occurs in Sphagnum with the addition of new taxonomic concepts (Flatberg \& Thingsgaard 2003,
Maksimov 2007, Maksimov \& Ignatova 2008) that have increased the number of species from 24 to 32: S. alaskense, S. platyphyllum, S. quinquefarium, S. rubiginosum, S. steerei, $S$. subfulvum and $S$. tundrae are added.

On the other hand, some habitats had not been carefully investigated in previous work. After these were thouroughly studied, a large number of taxa were newly recorded for the province, with the status on their rarity considerably changed. The study of snowbed habitats added Andreaea blyttii, $A$. nivalis, A. obovata, A. papillosa (only Andreaea rupestris was known in the province), Oligotrichum falcatum, Brachythecium turgidum, Polytrichastrum septentrionale and P. sphaerothecium to the moss flora. Taxa such as Arctoa fulvella, Poblia drummondii and Catoscopium nigritum can no longer be regarded as 'very rare' and sparsely occuring in the province. Similarly, the moss flora on limestone habitats and otherwise similar habitats with presumably slightly alkaline reaction, : the diversity of Encalypta increased from 3 to 8 taxa (E. affinis, E. alpina, E. brevicolla, E. brevipes, E. trachymitria were added), newly recorded are Amphidium lapponicum, Gymnostomum aeruginosum, Hymenostylium recurvirostrum, Мyurella julacea, $M$. tenerrima, Plagiopus oederianus. Many taxa that were previously regarded as rare are found in this series of new localities, and where sometimes even locally abundant: Aulacomnium acuminatum, Brachythecium cirrosum, Buxbaumia aphylla, Campylium stellatum, Cyrtomnium bymenopbylloides, Distichium capillaceum, Grimmia incurva, Hamatocaulis lapponicus, Myuroclada maximowiczii, Neckera pennata, Orthothecium strictum, Timmia austriaca, Tortula hoppeana, etc.

Despite relatively low landscape diversity, the territory of the Magadan Province was found to be very interesting taxonomically. The history of the biota development and current climatic situation provides the 'neighborhood' of some contrasting floristic complexes. The taxa of mostly hemiarctic and arctic-alpine distribution are quite abundant here: Aulacomnium turgidum, Bartramia ithyphylla, Cinclidium arcticum, Conostomum tetragonum, Dicranum elongatum, Hygrobypnella polaris, Meesia uliginosa, Oligotrichum falcatum, Paludella squarrosa, Poblia crudoides, Pseudocalliergon brevifolium, Racomitrium lanuginosum, Warnstorfia sarmentosa, etc. Along with some expected boreal taxa (Aulacomnium palustre, Climacium dendroides, Hygrohypnella ochracea, Niphotrichum canescens, Oncophorus wablenbergii, Plagiomnium ellipticum, P. medium, etc.), some hemiboreal and even temperate ones also occur (Myuroclada longiramea, M. maximowiczii, Pylaisia polyantha, Rhizomnium magnifolium, Thuidium assimile, etc.). The additional point is provided by taxa having an amphi-oceanic and amphi-Pacific distribution: Bryoxiphium norvegicum, Herzogiella adscendens, Oligotrichum parallelum, Sphagnum alaskense, Trachycystis flagellaris, Trematodon ambiguous. One of the most interesting records is Oedipodium griffithianum. This taxon is highly disjunct. In Russia this is the fourth and the northernmost location.

\section{ACKNOWLEDGEMENTS}

The English in the manuscript was kindly corrected by Dr. John Atwood (MO). The work is a result of biocollection development (AAAA-A17-117073110003-8, AAAA-A17-117012610052-2, USU 440534), and was partially supported by the Russian Foundation for Basic Re- 
search (grant 17-04-00018) and RSF (grant 18-14-00121). We are grateful to Ms. E.V. Malashkina and Mr. A.V. Ermolenko for specimen collecting in some areas, to Dr. E.A. Ignatova (MW) and Prof. M.S. Ignatov (MHA) for identification or revision of a number of taxonomically 'difficult' taxa, to Prof. Dr. Ryszard Ochyra for valuable remarks, as well as to our colleagues who helped us a lot to conduct field researches in the wild environments of Kolyma Upland: Prof. V.Yu. Barkalov (VLA), Dr. O.A. Mochalova (MAG), Ms. O.A. Deryugina (VBGI).

\section{LITERAT URE CITED}

Afonina, O.M. 2008. Stereodon (Brid.) Mitt. In: Moss flora of Russia. Online version (M.S. Ignatov, ed.), pp. 1-29 (in Russian). [Афонина O.M. 2004. Stereodon (Brid.) Mitt. // ФАора мхов России. Электронная публикация, 29 c.]. Available from: http://arctoa.ru/Flora/taxonomy-ru. php (last accessed 1.IX.2008).

Afonina, O.M. \& L.S. Blagodatskikh 2006. New moss records from Magadan Province. 1. Arctoa 15:268.

Afonina, O.M. \& E.A. Ignatova 2007. East Asian species of Stereodon (Brid.) Mitt. (Pylaisiaceae, Musci) in Russia. Arctoa 16:7-20.

Anderson, P.M., A.V. Lozhkin, A.Yu. Pakhomov, V.N Smirnov \& T.V. Stetzenko 2000. First palynological and radiocarbon data from the Holocene sediments on the vicinity of Magadan. In: The Quaternary period of Beringia (K.V. Simakov, ed.), pp. 8-19. SVKNI DVO RAN, Magadan (in Russian). [Андерсон П.М., Аожкин А.В., Пахомов А.Ю., Смирнов В.Н., Стеценко Т.В. 2000. Первые палинологические и радиоуглеродные данные о гомоценовых отложениях в окрестностях Магадана // Берингия в четвертичный период / поА реА. К.В. Симакова. Магадан: СВКНИ АВО РАН. С. 8-19].

Anonymous. Herbarium specimens of Russian mosses. Available from: http://arctoa.ru/Flora/basa.php. Last accessed 19.07.2018.

Berkutenko, A.N., D.S. Lysenko, M.G. Khoreva, O.A. Mochalova, A.N. Polezhaev, E.A. Andrijanova, N.V. Sinelnikova \& V.V. Yakubov 2010. Flora and vegetation of Magadan Region (Checklist of vascular plants and the outline of vegetation). IBPN FEB RAS, Magadan, 364 pp. (in Russian). [Беркутенко А.Н., Аысенко А.С., Хорева М.Г., Мочалова О.А., Полежаев А.Н., Андриянова Е.А., Синельникова Н.В., Якубов В.В. 2010. ФАора и растительность Магаданской области (конспект сосудистых растений и очерк растительности). МагаАан: ИБПС АВО РАН. 364 с.].

Blagodatskikh, L.S. \& J. Duda 1988. Liverworts of Kolyma Upland. SVKNII, Magadan, 29 pp. (in Russian). [Благодатских А.С., Ауда Й. 1988. Печеночные мхи Колымского Нагорья. Магадан: СВКНИИ. 29 с.].

Blagodatskikh, L.S. 1984. Mosses of Kolyma Upland. SVKNII, Magadan, 47 pp. (in Russian). [БАагодатских А.С. 1984. Аистостебельные мхи Колымского нагорья. Магадан: СВКНИ. 47 с.].

Chemeris, E.V. \& O.A. Mochalova 2015. New moss records in Magadan Province. 1. New bryophyte records. 4. (E.V. Sofronova, ed.). Arctoa 24:255-257 (in Russian) [Чемерис E.B., Мочалова О.А. 2015. Новые находки мохообразных в Магаданской области. 1. In: Sofronova E.V. (ed.) New bryophyte records. 4. Arctoa. 24:255-257].

Cherdantseva, V.Ya. \& V.A. Bakalin 2011. New moss records from Magadan province. 1. Arctoa 20:263.
Czernyadjeva, I.V. 1999. On the distribution of propaguliferous species of Poblia (Bryaceae, Musci) in Russia. Arctoa 8:51-56.

Czernyadjeva, I.V. 2004. The genus Hygrohypnum (Amblystegiaceae, Musci) in Russia. Arctoa 12:25-58 (in Russian with English summary). [Чернядьева И.В. 2004. РоА Hygrobypnum (Amblystegiaceae, Musci) в России // Arctoa. Вып. 12. С. 25-58].

Fedosov, V.E. 2012. Encalypta sect. Rhabdotheca in Russia. Arctoa 21:101-112.

Fedosov, V.E. \& E.A. Ignatova 2008. The genus Bryoerythrophyllum (Pottiaceae, Bryophyta) in Russia. Arctoa 17:19-38.

Fedosov, V.E. \& E.A. Ignatova 2011. On Orthotrichum pellucidum and O. hallii (Orthotrichaceae, Bryophyta) in Russia. Arctoa 20:197-204.

Fedosov, V.E. \& G.Ya. Doroshina 2018. Orthotrichales. In: Moss flora of Russia. Vol. 4: Bartramiales - Aulacomniales (M.S. Ignatov, ed.), pp. 67-195, Tovarishchestvo nauchnyh izdanij KMK, Moscow (in Russian with English abstracts). [Федосов В.Э., Аорошина Г.Я. 2018. Orthotrichales // Фцора мхов России. Том 4: Bartramiales-Aulacomniales / пол ред. М.С. Игнатова. Москва: Товарищество научных изданий КМК. С. 67-195].

Flatberg, K.I. \& K. Thingsgaard 2003. Taxonomy and geography of Sphagnum tundrae with a description of S. mirum, sp. nov. (Sphagnaceae, sect. Squarrosa). Bryologist 106(4):501-515.

Huttunen, S., O. Kuznetsova, M. Li, Y-F. Wang \& M.Ignatov 2015. East Asian origin and Northern Hemisphere diversification in the Brachythecium novae-angliae-complex (Bryophyta). Taxon 64(5):911-930.

Ignatov, M.S. 2012 Brachythecium Bruch, Schimp. \& Gümbel In: Moss flora of Russia. Online version (M.S. Ignatov, ed.), pp. 1-51 (in Russian). [Игнатов M.C. 2012. Brachythecium Bruch, Schimp. \& Gümbel / / Фцора мхов России. Электронная публикация, 51 c.]. Available from: http:/ / arctoa. ru/Flora/taxonomy-ru.php. Last accessed 1.09.2008.

Ignatov, M.S. \& E.A Ignatova 2008. Sciuro-hypnum (Hampe) Hampe. In: Moss flora of Russia. Online version (M.S. Ignatov, ed.), pp. 1-30 (in Russian). [Игнатов M.C., Игнатова Е.A. 2008. Sciuro-hypnum (Hampe) Hampe. // ФАора мхов России. Электронная пуб̆иикация 30 с.]. Available from: http://arctoa.ru/Flora/taxonomy-ru.php. Last accessed 01.09.2008.

Ignatov, M.S. \& I.A. Milyutina 2007a. A revision of the genus Sciuro-bypnum in Russia (Brachytheciaceae, Bryophyta). Arctoa 16:63-86.

Ignatov, M.S., O.M. Afonina \& E.A. Ignatova et al. 2006. Check-list of mosses of East Europe and North Asia. Arctoa 15: 1-130.

Ignatova, E.A. 2005. On the distribution of Dicranum species with tubulose liaves in Russia. In: Actual problems of Bryology (O.M. Afonina, A.D. Potemkin \& I.V. Chernyadjeva, eds), pp. 95-101, LETI, St-Peterburg (in Russian). [Игнатова Е.А. 2015. О распространении видов Dicranum с трубчато свернутыми Аистьями в России // Актуальные проблемы бриологии / поА реА. О.М. Афониной, А.А. Потемкина, И.В. Чернядьевой. СПб: ИзА-во СПбГЭТУ “АЭТИ”, 2005. С. 95-101].

Ignatova, E.A. \& H.H. Blom 2017. Grimmia. In: Moss flora of Russia. Volume 2: Oedipodiales-Grimmiales (M.S. Ignatov, ed.), pp. 362-428. Tovarishchestvo nauchnyh izdanij KMK, Moscow (in Russian with English abstracts) [Игнатова 
Е.А., БАом Х.Х. 2017. Grimmia // Фцора мхов России. Том 2: Oedipodiales-Grimmiales/ под ред. М.С. Игнатова. Москва: Товарищество научных изданий КМК. C. $362-428]$.

Ignatova, E.A. \& J.T. Muñoz 2004. The genus Grimmia Hedw. (Grimmiaceae, Musci) in Russia. Arctoa 13:101-182.

Ivanova E.I., M.S. Ignatov, A.I.Milyutina \& V.K. Bobrova 2005. On the morphological and molecular differences between Oligotrichum hercinicum and O. falcatum (Polytrichaceae, Bryophyta). Arctoa 14:1-12.

Ivanova, E.I., N.E. Bell, O.I. Kuznetsova, H. Lee, M. Park \& M.S. Ignatov 2014. The genus Polytrichastrum (Polytrichaceae) in Russia. Arctoa 23:164-184.

Kharkevich, S.S. 1984. The origin and composition of Kamchatka vascular plant flora. In: Istoriya rastitel'nogo pokrova Severnoy Asii. (L.I. Malyshev, ed.), pp. 107-117, Nauka, Novosiborsk (in Russian) [Харкевич C.C. 1984. Происхождение и состав флоры сосудистых растений Камчатки // История растительного покрова Северной Азии / под ред. А.И. Малышева.. Новосибирск: Наука. С. 107-117].

Khokhriakov, A.P. 1985. Flora of Magadan Province. Nauka, Moscow, 398 pp. (in Russian). [Хохряков А.П. 1985. ФАора Магаданской области. М.: Наука, 398 с.].

Khokhryakov, A.P. 1989. The analysis of the flora of Kolyma Upland. Nauka, Moscow, 152 pp. (in Russian). [Хохряков А.П. 1989. Анализ флоры Колымского нагорья. М.: Наука, 152 с.].

Komarov, V.L. 1950. The journey to Kamchatka in 1908-1909. Selected works. Vol. VT. Izdatel'stvo Akademii Nauk SSSR, Moscow, Leningrad, 527 pp. (in Russian). [Комаров B. $\Lambda$. 1950. Путешествие по Камчатке в 1908-1909 гг. Избранные сочинения. Т. VI. М.; А.: ИзА-во Академии наук СССР, 527 с.].

Kovel', L.V. (ed.) 1990. Scientific and applied climate reference book of the USSR. Series 3. Long-term data. Magadan Province, Chukotka Autonomous District of Magadan Province vol. 33, parts 1-6, Gidrometeoizdat, Saint-Petersburg, 567 pp. (in Russian). [Ковель А.В. (реА.) 1990. Научно-приклаАной Справочник по климату СССР. Серия 3. Многолетние Аанные. Магаданская об̆ласть, Чукотский автономный округ Магаданской области. СПб: Гилрометеоиздат. Вып. 33, ч. 11-6. 567 с.].

Lozhkin, A.V. 1997. Environmental history of Beringia during the late Pleistocene and Holocene: Some results of joint Russian-American research. In: Late Pleistocene and Holocene of Beringia (M.Kh. Gagiev, ed.), pp. 5-22, SVKNI DVO RAN, Magadan (in Russian). [Аожкин А.В. 1997. Эволюция природной среды Берингии в позАнем плейстоцене и голоцене: некоторые итоги совместных российскоамериканских исследований // Поздний плейстоцен и голоцен Берингии / под ред. М.Х. Гагиева. Магадан: СВКНИ АВО РАН. С. 5-22].

Lozhkin, A.V. \& O.Yu. Glushkova 1997a. New palinological assemblages and radiocarbon dates from late Quaternary deposits of northern Priokhot'ye. In: Late Pleistocene and Holocene of Beringia (M.Kh. Gagiev, ed.), pp. 70-79, SVKNI DVO RAN, Magadan (in Russian). [Аожкин A.B., ГАушкова О.Ю. 1997а. Новые палинологические характеристики и радиоуглеродные датировки верхнечетвертичных отможений Северного Приохотья / / ПозАний плейстоцен и голоцен Берингии / под ред. М.Х. Гагиева. МагаАан: СВКНИ АВО РАН. С. 70-79].

Lozhkin, A.V. \& O.Yu. Glushkova 1997b. Boreal age peats from the Upper Kolyma basin. In: Late Pleistocene and Holo- cene of Beringia (M.Kh. Gagiev, ed.), pp. 55-62, SVKNI DVO RAN, Magadan (in Russian). [Аожкин A.B., ГАушкова О.Ю. 1997b. Бореальные торфяники в бассейне Верхней Колымы // Поздний плейстоцен и голоцен Берингии / под реА. М.Х. Гагиева. Магадан: СВКНИ $\triangle B O$ PAH. C. 55-62].

Lozhkin, A.V., P.M. Anderson, O.Yu. Glushkova, T.B. Solomatkina \& I.N. Fedorova 2000. About features of development of lakes in the mountain regions of the Upper Kolyma. In: The Quaternary period of Beringia (K.V. Simakov, ed.), pp. 20-45, SVKNI DVO RAN, Magadan (in Russian). [Аожкин А.В., Андерсон П.М., ГАушкова О.Ю., Соломаткина Т.Б., Федорова И.Н. 2000. О некоторых особенностях озер в горных районах Верхней Колымы // Берингия в четвертичный периоА / под реА. К.В. Симакова. МагаАан: СВКНИ АВО РАН. С. 20-45].

Maksimov, A.I. 2007. Sphagnum imbricatum complex (Sphagnaceae, Bryophyta) in Russia. Arctoa 16:25-34.

Maksimov, A.I. \& E.A. Ignatova 2008. Sphagnum alaskense (Sphagnaceae, Bryophyta), a new species for Russia. Arctoa 17:109-112.

Maksimov, A.I., V.E. Fedosov \& E.A. Ignatova 2016. Sphagnum beringiense (Sphagnaceae, Bryophyta) in Russia. Arctoa 25:102-106.

Malashkina, E.V. 2012. New moss records from Magadan Province. 3. New bryophyte records. 1. (E.V. Sofronova, ed.). 1. Arctoa 21:295.

Pisarenko, O.Yu. 2015a. Mosses of the Bolshoi Annachag Range (Magadan Province, Russian Far East). Arctoa 24(1):187-193.

Pisarenko, O.Yu. 2015b. New moss records from Magadan Province. New bryophyte records. 4. (E.V. Sofronova, ed.). Arctoa 24(1):252-255.

Pisarenko, O.Yu. 2015c. To the bryoflora of Magadan Province (Russian Far East). In: Proceedings of the international bryolodical conference dedicated to 100- anniversary from A.L. Abramova birthday (St Petersburg, 12-16 October 2015), pp. 109-113, LETI, St-Peterburg (in Russian). [Писаренко О.Ю. 2015. К бриофлоре Магаданской области (Российский Аальний Восток) // Материалы межАународной бриологической конференции, посвященной 100-летию со Аня рожАения А.. . Абрамовой (Санкт-Петербург, 12-16 октября 2015 г.) СПб: ИзА-во СПбГЭТУ “АЭТИ”, 2015. С. 109-113].

Pisarenko, O.Yu., V.E. Fedosov \& V.A. Bakalin 2015. Mosses of the Russian Far East. Exiccatae. Fasc.I (№№ 1-35). Vladivostok. $12 \mathrm{pp}$.

Tubanova D.Ya. \& E.A. Ignatova 2011. A new species of Dicranum (Dicranaceae, Bryophyta) from Asiatic Russia. Arctoa 20:183-190.

Tubanova, D.Ya., D.V. Goryunov, E.A. Ignatova \& M.S. Ignatov 2010. On the taxonomy of Dicranum acutifolium and D. fuscescens complexes (Dicranaceae, Bryophyta) in Russia. Arctoa 19:151-164.

Yurtzev, B.A. \& A.P. Khokhryakov 1975. An analysis of the flora of the Olskoye Plateau (in connection with the history of the plant cover of the Kolyma Mountains). Bulleten'. Moskouskogo obshchestva ispytatelei prirody. Otdelenie biologii 80(2): 120-133 (in Russian). [Юрцев Б.А., Хохряков А.П. 1975. Анализ флоры Ольского плато (в связи с историей растительного покрова Колымского нагорья) // Бюлм. МОИП, отА. биол. Т. 80, №. 2. С. 120-133]. 
Yurtzev, B.A. 1966. Hypoarctic botanical-geogrphical band and the origin of its flora. Komarovskiye Chteniya 19. Nauka, Leningrad, 94 pp. (in Russian). [Юрцев Б.А. 1966. Гипоарктический ботанико-географический пояс и происхождение его флоры // Комаровские чтения. Вып. 19. А.: Наука, 94 с.].

Yurtzev, B.A. 1974. The problems in botanical geography of NorthEast Asia. Nauka, Leningrad, 159 pp. (in Russian). [Юpцев Б.А. 1974. Проблемы ботанической географии Северо-восточной Азии. А.: Наука, 159 с.].
Zolotov, V.I. 2018. Bryum. In: Moss flora of Russia. Vol. 4. Bartramiales - Aulacomniales (M.S. Ignatov, ed.), pp. 255360. Tovarishchestvo nauchnyh izdanij KMK, Moscow (in Russian with English abstracts). [Золотов В.И. 2018. Bryum // ФАора мхов России. Том 4: BartramialesAulacomniales / под ред. М.С. Игнатова. Москва: Товарищество научных изданий КМК. С. 255-360]. 